Miljan Leković

Fakultet za hotelijerstvo i turizam u Vrnjačkoj Banji, Univerziteta u Kragujevcu m.lekovic@kg.ac.rs

Prevod obezbedio

autor
ALTERNATIVNE MERE I

DEKOMPOZICIJA PERFORMANSI PORTFOLIJA INVESTICIONIH FONDOVA

\title{
Rezime
}

Pored $\mathrm{u}$ teoriji najčešće korišćenih i u praksi potpuno afirmisanih mera performansi portfolija: Šarpovog, Trejnorovog i Jensenovog ili alfa indeksa, u finansijskoj literaturi su se izdvojile i dve modifikovane verzije Šarpovog indeksa: informacioni racio i $M^{2}$ mera performansi portfolija, jedna modifikovana verzija Trejnorovog indeksa: $T^{2}$ mera performansi portfolija, modeli koji mere menadžersku sposobnost tajminga tržišta: Treynor-Mazuy i Henriksson-Merton model, i racio zasnovan na negativnom riziku i negativnoj devijaciji kao njegovoj meri: Sortinov racio. Cilj rada je da se investiciona javnost u Republici Srbiji bliže upozna sa osnovnim odlikama navedenih mera performansi portfolija, kao i da se razume važnost dekompozicije ostvarenih performansi portfolija investicionih fondova.

Ključne reči: informacioni racio, $M^{2}$ mera performansi, $T^{2}$ mera performansi, Treynor-Mazuy model, Henriksson-Merton model, Sortinov racio 


\section{ALTERNATIVE \\ MEASURES AND \\ DECOMPOSITION \\ OF MUTUAL \\ FUNDS PORTFOLIO \\ PERFORMANCE}

Miljan Leković

School for Hotel Management and Tourism in Vrnjačka Banja, University of Kragujevac m.lekovic@kg.ac.rs
Translation provided by the author

\section{Summary}

In addition to the well-established and most commonly used portfolio performance measures, both in theory and practice - the Sharpe ratio, the Treynor ratio and the Jensen's or alpha index, the financial literature also includes other alternative portfolio measures, such as: two modified versions of the Sharpe ratio - the information ratio and the $M^{2}$ portfolio performance measure, one modified version of the Treynor ratio - the $T^{2}$ portfolio performance measure, models that measure the market timing abilities of fund managers - the Treynor-Mazuy and the Henriksson-Merton model and a ratio based on the downside risk and the downside deviation as its measure - the Sortino ratio. The paper aims to inform the investors in the Republic of Serbia about the basic features of the aforementioned portfolio performance measures, as well as to point to the importance of understanding the decomposition of the actual portfolio performance of mutual funds.

Keywords: information ratio, $M^{2}$ performance measure, $T^{2}$ performance measure, Treynor-Mazuy model, Henriksson-Merton model, Sortino ratio 


\section{Uvod}

Izbor konkretnog investicionog fonda kojem će investitori poveriti slobodna novčana sredstva, po pravilu, započinje odabirom vrste investicionih fondova koja odgovara investitorovim preferencijama i definisanim investicionim ciljevima. Izbor vrste fondova od strane pojedinačnih i institucionalnih investitora zavisi, s jedne strane, od definisane investicione politike i postavljenih investicionih ciljeva investicionih fondova, a s druge strane, od preferencija i investicionih ciljeva samih investitora. Za očekivati je da konzervativniji investitori sa niskim nivoom tolerancije rizika i postavljenim ciljem obezbeđenja sigurnosti ulaganja i očuvanja vrednosti imovine, investiraju slobodna novčana sredstva $u$ novčane fondove. $S$ druge strane, agresivniji investitori sa visokim nivoom tolerancije rizika i postavljenim ciljem postizanja visokih kapitalnih dobitaka obično investiraju slobodna novčana sredstva u fondove akcija.

Nakonodabira preferirane vrsteinvesticionih fondova, izbor konkretnog investicionog fonda dominantno zavisi od ostvarenih performansi njegovog portfolija. Natprosečne performanse portfolija investicionog fonda ostvarene zahvaljujući sposobnostima portfolio menadžera (sposobnosti izbora najboljih hartija od vrednosti za dati nivo rizika (selection ability) i/ili sposobnosti predviđanja tržišnih fluktuacija i pravovremenog prilagođavanja strukture portfolija nastupajućim promenama (timing ability)) su snažan podsticaj investitorima za ulaganje $u$ dati fond. Stoga je iz ugla pojedinačnih i institucionalnih investitora važno izvršiti ocenu performansi portfolija investicionih fondova.

Ocena performansi portfolija je podjednako važna i za menadžere investicionih fondova, jer ih informiše o kvalitetu i uspešnosti kreiranog portfolija. Saznanja ove vrste usmeravaju delovanje portfolio menadžera $u$ pravcu unapređenja efikasnosti kreiranog portfolija.

Pored ocene performansi portfolija važno je da se razume i uzrok dobrih ili loših performansi investicionih fondova. Da li su, na primer, natprosečni rezultati ostvareni zahvaljujući selekcionoj sposobnosti ili sposobnosti tajminga tržišta portfolio menadžera? Da li portfolio menadžer poseduje ili ne poseduje potrebnu veštinu izbora hartija od vrednosti? Da li tajming tržišta donosi dodatne koristi ili samo dodatne transakcione troškove (Elton i saradnici, 2011)? Drugim rečima, važno je izvršiti dekompoziciju ostvarenih performansi portfolija investicionih fondova.

\section{Mere performansi portfolija}

U vreme važenja tradicionalne portfolio teorije rizik nije bio predmet analize, a performanse portfolija su ocenjivane isključivo na osnovu ostvarene stope prinosa. Razvoj savremene portfolio teorije (Modern Portfolio Theory - MPT) omogućio je korekciju prinosa za rizik i poređenje rizikom ponderisanih prinosa portfolija. Prve mere performansi portfolija koje su na adekvatan način korigovale prinos za rizik pojavile su se sa ravojem modela vrednovanja kapitalne aktive (Capital Asset Pricing Model CAPM). Džek Trejnor (Jack Treynor) (1965), Vilijam Šarp (William Sharpe) (1966) i Majkl Jensen (Michael Jensen) (1968) su, polazeći od CAPM modela, nezavisno jedan od drugoga uveli standardne mere performansi poznate kao Trejnorov, Šarpov i Jensenov ili alfa indeks. Treba istaći da su i pre ovih modela postojali pokušaji ocene performansi portfolija zasnovani na Markovicevoj portfolio teoriji i odnosu prinosa i rizika. Međutim, rane analize bazirane na MPT nisu uspele da obezbede metodologiju naučnog rangiranja portfolija po osnovu ostvarenih performansi. Rangiranje portfolija je omogućeno tek sa pojavom Šarpovog i Trejnorovog racija, zahvaljujući činjenici da ovi indeksi svode prinos i rizik portfolija na jedan broj koji je pogodan za rangiranje.

Kao naslednik i modifikovana verzija Šarpovog indeksa pojavio se najpre informacioni racio, a potom i $M^{2}$ mera performansi portfolija koju su iz Šarpovog indeksa izveli dobitnik Nobelove nagrade za ekonomiju Franko Modiljani (Franco Modigliani) i njegova unuka Lea Modiljani (Leah Modigliani). Mera analogna $M^{2}$ meri performansi portfolija, uvedena u cilju lakšeg tumačenja numeričke vrednosti Trejnorovog indeksa, je $T^{2}$ mera performansi portfolija.

Pored navedenih mera, $\mathrm{u}$ finansijskoj literaturi su se izdvojili Treynor-Mazuy 


\section{Introduction}

The selection of a particular mutual fund to which the investors choose to entrust their assets, as a rule, starts by selecting the type of mutual fund that would best suit the client's preferences and defined investment objectives. Selecting the particular type of mutual fund, both by the individual and institutional investors depends, on the one hand, on the defined investment policy and the mutual fund's investment objective, and on the other hand, on the preferences and investment objectives of the investors. It is to be expected that more conservative investors with low risk tolerance and defined investment objectives which include investment security and preservation of the value of assets, invest their assets into money market (cash funds). On the other hand, the more aggressive investors with high risk tolerance and defined investment objectives that include achievement of high capital gains, typically invest their assets in equity funds.

After selecting the preferred type of mutual funds, the choice of a particular mutual fund predominantly depends on its actual portfolio performance. The above average performance of mutual funds, achieved thanks to the selection ability and/or timing ability of portfolio managers, represents a strong incentive for investors to invest in a certain fund. Therefore, from the viewpoint of both individual and institutional investors, it is important to evaluate portfolio performance of mutual funds.

Portfolio performance evaluation is equally important for the managers of mutual funds, as it informs them on the quality and performance of the constructed portfolio. This kind of information helps portfolio managers to increase the efficiency of constructed portfolios.

In addition to the portfolio performance evaluation, it is important to understand the reasons behind successful or poor performance of mutual funds. Whether, for example, the above-average results were achieved thanks to the selection ability or timing ability of the portfolio manager? Does the portfolio manager possess or lack the necessary skills for selecting securities? Does the proper timing bring additional benefits or just additional transaction costs (Elton et al., 2011)? In other words, it is important to break down, i.e. decompose the actual portfolio performance of mutual funds.

\section{Portfolio Performance Measures}

At the time when the traditional portfolio theory was widely accepted, risk was not included in any type of analysis and portfolio performance was evaluated solely on the basis of actual rates of return. The development of the Modern Portfolio Theory (MPT) introduced risk-adjustment of returns and comparison of the risk-weighted returns. The first portfolio evaluation measures that provided adequate solutions for risk-adjusting portfolio returns emerged at the time of Capital Asset Pricing Model (CAPM) development. Building upon the CAPM, Jack Treynor (1965), William Sharpe (1966) and Michael Jensen (1968), independently of each other, developed the standard performance measures known as the Treynor ratio, the Sharpe ratio and the Jensen's or alpha index. It should be noted that, prior to the emergence of the aforementioned models, there were some attempts to evaluate portfolio performance based on the Markowitz's portfolio theory and risk to return ratio. However, these early analyses based on MPT failed to provide the scientific methodology which would provide ranking of portfolios based on their actual performance. Portfolio ranking was made possible with the development of the Treynor and the Sharpe ratios, due to the fact that these ratios reduce portfolio returns and risks to a single number, which is suitable for ranking purposes.

The information ratio was developed first as the successor and the modified version of the Sharpe ratio, and was followed by the development of the $M^{2}$ measure of portfolio performance, also derived from the Sharpe ratio by the Nobel Prize-winning economist Franco Modigliani and his granddaughter Leah Modigliani. Another measure of portfolio performance, analogue to $M^{2}$ was also introduced in order to facilitate the interpretation of the numerical value of the Treynor ratio. This measure is known as the Treynor Square - $T^{2}$.

In addition to the aforementioned measures, 
i Henriksson-Merton model, koji mere sposobnost tajminga tržišta portfolio menadžera investicionih fondova. Za razliku od Jensenovog indeksa koji analizira selekcionu sposobnost portfolio menadžera investicionih fondova, ovi modeli ispituju sposobnost portfolio menadžera da predvide tržišne fluktuacije i pravovremeno reaguju na iste.

Konačno, razvoj post-savremene portfolio teorije (Post-Modern Portfolio Theory - PMPT) uslovio je pojavu još jedne važne mere performansi portfolija. U pitanju je Sortinov racio zasnovan na negativnom riziku i negativnoj devijaciji kao njegovoj meri.

Budući da je Šarpovom, Trejnorovom i Jensenovom indeksu u relevantnoj literaturi posvećena značajna pažnja, u nastavku teksta, analizirane su domaćoj investicionoj javnosti manje poznate mere performansi portfolija: informacioni racio, $M^{2}$ i $T^{2}$ mera performansi, Treynor-Mazuy i Henriksson-Merton model i Sortinov racio.

\section{Informacioni racio}

Informacioni racio (information ratio) predstavlja modifikovanu verziju Šarpovog indeksa. Najveće zasluge za njegov razvoj imaju Treynor i Black (1973), koji su ovaj racio inicijalno nazvali racio procene (appraisal ratio). Za razliku od Šarpovog indeksa koji razliku između prinosa portfolija i prinosa nerizične aktive stavlja $u$ odnos sa ukupnim rizikom, informacioni racio razliku između prinosa portfolija i prinosa izabranog benčmarka stavlja u odnos sa aktivnim rizikom. Informacioni racio se $\mathrm{u}$ finansijskoj literaturi često označava kao varijacija Šarpovog indeksa nastala upotrebom prinosa na benčmark umesto prinosa na nerizičnu aktivu i upotrebom aktivnog umesto ukupnog rizika. Računa se stavljanjem $\mathrm{u}$ odnos viška prinosa portfolija u odnosu na izabrani benčmark, sa njegovom standardnom devijacijom:

$$
I R=\frac{\bar{r}_{p}-\bar{r}_{m}}{\sigma_{\left(r_{p}-r_{m}\right)}},
$$

gde su:

$I R$ - informacioni racio,

$\bar{r}_{p}-\bar{r}_{m}$ - višak prinosa portfolija u odnosu na izabrani benčmark,

$\sigma_{\left(r_{p}-r_{m}\right)}$ - standardna devijacija viška prinosa portfolija u odnosu na izabrani benčmark.
Višak prinosa portfolija $u$ odnosu na izabrani benčmark se naziva još i aktivni prinos (active return), dok se standardna devijacija viška prinosa naziva aktivni rizik (active risk), rizik praćenja (tracking risk) ili greška praćenja (tracking error). Aktivni prinos i aktivni rizik su prinos i rizik nastali aktivnim upravljanjem portfoliom, odnosno, kreiranjem portfolija različitog od benčmarka. Nije teško zaključiti da informacioni racio predstavljen odnosom aktivnog prinosa i aktivnog rizika, pokazuje iznos ostvarenog aktivnog prinosa po jedinici preuzetog aktivnog rizika. Drugim rečima, ovaj racio pruža informaciju o iznosu dodatnog prinosa ostvarenog po jedinici dodatnog rizika.

Veći informacioni racio znači bolje performanse portfolija investicionog fonda. Pozitivan informacioni racio ukazuje da je odluka o kreiranju portfolija koji se razlikuje od izabranog benčmarka rezultirala viškom prinosa portfolija, tj. višim prinosom portfolija od prinosa benčmarka. S druge strane, negativan informacioni racio ukazuje da je odluka o kreiranju portfolija koji se razlikuje od benčmarka rezultirala nižim prinosom portfolija od prinosa izabranog benčmarka. Dakle, informacioni racio meri koristi aktivnog upravljanja portfoliom i ukazuje na sposobnost aktivnog portfolio menadžera da maksimira aktivni prinos po jedinici aktivnog rizika. Portfolio koji savršeno kopira benčmark imaće aktivni prinos jednak nuli i nultu grešku praćenja. Međutim, portfolio kojim se aktivno upravlja i koji zauzima pozicije značajno različite od benčmarka imaće značajan aktivni prinos, kako pozitivan tako i negativan, i samim tim imaće grešku praćenja na godišnjem nivou od npr. 5\% ili 10\% (Fabozzi i saradnici, 2011a).

Informacioni racio je zasnovan na Markovicevoj portfolio teoriji i primenljiv isključivo na portfolije koji imaju normalnu distribuciju očekivanih prinosa. On pokazuje da li je portfolio menadžer investicionog fonda uspeo da nadmaši tržište na rizikom ponderisanojosnovi, alineuspeva da pokaže dali su ti rezultati ostvareni zahvaljujući sposobnosti portfolio menadžera ili sreći. Informacioni racio je visoko zavistan od vremenskog perioda koji se razmatra. Preferirani informacioni racio se može dobiti manipulacijom vremenskog perioda, u smislu uključivanja $u$ analizu perioda 
the financial literature also draws attention to two models: the Treynor-Mazuy model and the Henriksson-Merton model, both of which measure the market timing skills of portfolio managers. Apart from the Jensen's alpha, which analyzes the selection ability of portfolio managers, these models examine the ability of portfolio managers to anticipate market fluctuations and address them in a timely manner.

Finally, the development of the PostModern Portfolio Theory (PMPT) initiated the development of yet another important portfolio performance measure. This is the Sortino ratio, which is based on the downside risk and the downside deviation as its measure.

Considering that the reference literature offers a lot of information on the Sharpe, Treynor and Jensen's indices, the following sections of the paper analyze the portfolio performance measures that are less known in the investors' circles in Serbia: the information ratio, the $M^{2}$ and the $T^{2}$ performance measures, the TreynorMazuy and the Henriksson-Merton models and the Sortino ratio.

\section{Information Ratio}

The information ratio is a modified version of the Sharpe ratio. The majority of the work on the information ratio development was done by Treynor and Black (1973), who initially named this ratio the appraisal ratio. However, while the Sharpe ratio looks at the difference between the portfolio return and the risk-free asset return in relation to the overall risk, the information ratio examines the difference between the portfolio return and the return of the selected benchmark in relation to the active risk. In financial literature, the information ratio is often referred to as a variation of the Sharpe ratio, which was developed as a result of substituting the riskfree rate with the return of the benchmark and the overall risk with the active risk. The information ratio is calculated by dividing the excess return of the portfolio relative to its selected benchmark by the standard deviation of the excess return:

$$
I R=\frac{\overline{r_{p}}-\bar{r}_{m}}{\sigma_{\left(r_{p}-r_{m}\right)}},
$$

where:

$I R$ - denotes the information ratio, $\bar{r}_{p}-\bar{r}_{m}$ - denotes the excess return of the portfolio relative to its selected benchmark,

$\sigma_{\left(r_{p}-r_{m}\right)}$ - denotes the standard deviation of the excess return of the portfolio relative to its selected benchmark.

The excess return of the portfolio relative to its selected benchmark is also referred to as the active return, while the terms: active risk, tracking risk and tracking error are also used interchangeably to denote the standard deviation of the excess return. Active return and active risk are the results of the active portfolio management, i.e. the creation of a portfolio different from the benchmark. Therefore, it can be concluded that the information ratio calculated as a ratio of active return to active risk represents the value of actual active return per unit of active risk. In other words, this ratio provides the information about the amount of excessive return achieved per unit of extra risk.

Higher values of the information ratio indicate a better portfolio performance. A positive value of the information ratio indicates that the decision of a portfolio manager to create a portfolio that differs from the chosen benchmark resulted in excess return, i.e. the portfolio return outperformed the benchmark return. On the other hand, a negative value of the information ratio indicates that the decision to create a portfolio that differs from the benchmark resulted in a lower portfolio return than that of a chosen benchmark. Thus, the information ratio measures the rewards of active portfolio management and indicates the level of skill of an active portfolio manager to maximize the active return per unit of active risk. In terms of a portfolio that is created to perfectly match the benchmark, the active return equals zero, as well as the tracking error. However, an actively managed portfolio, substantially deviating from the benchmark, has large active returns, both positive and negative, and therefore, will have an annual tracking error of, say, $5 \%$ or $10 \%$ (Fabozzi et al, 2011a).

Since the information ratio is based on the Markowitz's portfolio theory, it is applicable only to portfolios with normal expected return distributions. This ratio actually shows whether the portfolio manager of a mutual fund managed to outperform the market on a risk-adjusted basis or not, however, it cannot provide the 
sa dobrim, a isključivanja iz analize perioda sa lošim rezultatima. Takođe, informacioni racio je visoko zavistan i od izbora benčmarka. Goodwin (1998) je u svom istraživanju pokazao da porfolio menadžeri čiji se rezultati stavljaju u odnos sa Standard and Poor's Industrials (SEP 500) indeksom kao benčmarkom imaju informacioni racio niži od informacionog racija portfolio menadžera čiji se rezultati stavljaju u odnos sa Russell 1000 indeksom kao benčmarkom. Slično, ukazao je i da je informacioni racio izračunat na osnovu Russell 2500 indeksa kao benčmarka, niži od informacionog racija izračunatog na osnovu Russell 2000 indeksa kao benčmarka. Navedeni rezultati idu u prilog tvrdnji da izbor benčmarka snažno utiče na vrednost informacionog racija (CFA Institute, 2011).

Informacioni racio se može prikazati i $\mathrm{u}$ formi prilagođenog Jensenovog indeksa. Računa se stavljanjem u odnos Jensenove alfe i nesistemskog rizika merenog rezidualnom standardnom devijacijom:

$$
I R=\frac{\alpha_{i}}{\sigma_{s i}}
$$

gde su:

$\alpha_{i}$ - Jensenov ili alfa indeks,

$\sigma_{\varepsilon i}$ - standardna devijacija reziduala portfolija.

Ovako prikazan informacioni racio se koristi za utvrđivanje doprinosa nove aktive ukupnim performansama portfolija. Primera radi, ukoliko se performanse portfolija mere Šarpovim indeksom i ukoliko se aktivno upravljani portfolio $A$ doda pasivno upravljanom indeksnom portfoliju $m$, Šarpov indeks novonastalog portfolija $q$ biće (Francis \& Kim, 2013):

$$
S_{q}^{2}=S_{m}^{2}+\left(\frac{\alpha_{A}}{\sigma_{\varepsilon A}}\right)^{2}
$$

gde su:

$S_{q}^{2}$ - kvadrirani Šarpov indeks novonastalog portfolija $q$,

$S_{m}^{2}$ - kvadrirani Šarpov indeks portfolija $m$, $\left(\frac{\alpha_{A}}{\sigma_{\varepsilon 1}}\right)^{2}$ - kvadrirani informacioni racio.

$\sigma_{\varepsilon A}$ Prethodna jednačina pokazuje da je doprinos aktivno upravljanog portfolija $A$ ukupnim performansama novonastalog portfolija $q$ određen odnosom Jensenove alfe i rezidualne standardne devijacije za ovaj portfolio. Drugim rečima, doprinos je određen visinom informacionog racija, zbog čega su najbolji investicioni kandidati za ulazak u portfolio oni koji imaju najveći informacioni racio.

Dakle, za razliku od Šarpovog indeksa koji pokazuje pojedinačne performanse aktivnih portfolija kao investicionih kandidata, informacioni racio pokazuje njihove potencijalne doprinoseukupnim performansama. Rangiranje investicionih kandidata prema Šarpovom indeksu predstavlja njihovo rangiranje prema pojedinačnim performansama, dok rangiranje investicionih kandidata prema informacionom raciju predstavlja njihovo rangiranje prema doprinosu ukupnim performansama. Konačno, uključivanjem $u$ portfolio investicionog kandidata sa najvećim informacionim raciom, postiže se maksimiranje performansi portfolija kao krajnji investicioni cilj.

\section{$M^{2}$ mera performansi}

Uprkos činjenici da se Šarpov indeks može koristiti za rangiranje portfolija prema ostvarenim performansama, tumačenje numeričke vrednosti ovog indeksa je teško i zahtevno. Ukoliko je Šarpov indeks za proizvoljni portfolio $p$ veći od Šarpovog indeksa za tržišni portfolio $m$, performanse portfolija $p$ su bolje od prosečnih tržišnih performansi, ali ostaje nepoznato za koliko su bolje. U nameri da odgovore na ovo pitanje dobitnik Nobelove nagrade za ekonomiju Franko Modiljani i njegova unuka Lea Modiljani su iz Šarpovog indeksa izveli meru performansi portfolija poznatu kao $M^{2}$ mera performansi ili Modiljani na kvadrat mera performansi portfolija (Modigliani \& Modigliani, 1997).

Osnovna ideja od koje su autori pošli podrazumeva izjednačavanje ukupnog rizika portfolija $p$ sa ukupnim rizikom tržišnog portfolija $m$, nakon čega se njihove performanse mogu uporediti jednostavnim poređenjem njihovih prinosa. Izjednačavanje ukupnog rizika portfolija $p$ sa ukupnim tržišnim rizikom zahteva kombinovanje portfolija $p$ sa bezrizičnom aktivom ili pak uvođenje leveridža. Ukoliko je standardna devijacija portfolija $p$ veća od standardne devijacije tržišnog portfolija $m$, izjednačavanje ukupnih rizika posmatranih portfolija se postiže kombinovanjem portfolija $p$ sa bezrizičnom aktivom. Međutim, ukoliko je standardna devijacija portfolija $p$ manja od 
information about whether the results were achieved thanks to the skills of portfolio managers or pure luck. The information ratio is highly dependent on the time period for which the measurement is conducted. A favorable value of the information ratio can be obtained by manipulating the measurement period, i.e. by including favorable performance periods into the analysis and excluding the unfavorable ones. Furthermore, the information ratio is highly dependent on the choice of a benchmark. The research done by Goodwin (1998) showed that portfolio managers whose results are benchmarked against the Standard and Poor's Industrials (SEP 500) Index as a proxy had a lower information ratio than those portfolio managers benchmarked against the Russell 1000 Index. He also showed that the information ratio calculated based on the Russell 2500 Index as a proxy is lower than the information ratio calculated based on the Russell 2000 Index as a proxy. These results support the position that the choice of a benchmark has a considerable effect on the value of the information ratio (CFA Institute, 2011).

The information ratio can also be represented as a modified version of the Jensen's index. It is calculated as the ratio between the Jensen's alpha and non-systemic risk measured by the residual standard deviation:

$$
I R=\frac{\alpha_{i}}{\sigma_{s i}}
$$

where:

$\alpha_{i}$ - denotes the Jensen's alpha or index,

$\sigma_{\varepsilon i}$ - denotes the standard deviation of portfolio residuals.

The information ratio denoted in this way is used to determine the contribution of the new assets to the overall portfolio performance. For example, if the portfolio performance is measured by the Sharpe ratio, and if the activelymanaged portfolio $A$ is added to the passivelymanaged index portfolio $m$, the Sharpe ratio of the new optimal portfolio $q$ constructed by using portfolios $A$ and $m$ is denoted as follows (Francis \& Kim, 2013):

$$
S_{q}^{2}=S_{m}^{2}+\left(\frac{\alpha_{A}}{\sigma_{\varepsilon A}}\right)^{2}
$$

where:

$S_{q}^{2}$ - denotes the squared Sharpe ratio of the new optimal portfolio $q$,

$S_{m}^{2}$ - denotes the squared Sharpe ratio of the portfolio $m$,

$\left(\frac{\alpha_{A}}{\sigma_{\sigma_{1}}}\right)^{2}$ - denotes the squared information ratio.

The above equation shows that the contribution of the actively-managed portfolio $A$ to the overall performance of the newly constructed portfolio $q$ is determined by the ratio of its Jensen's alpha to its residual standard deviation. In other words, the contribution is determined by the value of the information ratio, therefore, the best investment candidates to be included into a particular portfolio are those that have the highest values of the information ratio.

Thus, in contrast to the Sharpe ratio which measures the individual performance of active portfolios as the investment candidates, the information ratio shows their potential contribution to the overall performance. The ranking of investment candidates by means of the Sharpe's ratio should be used to evaluate individual performance, while the ranking of investment candidates by means of the information ratio represents the ranking according to the contribution to the overall performance. Finally, by including the investment candidate with the highest information ratio value into the portfolio, the ultimate objective of an investment -i.e. portfolio performance maximization, is achieved.

\section{$M^{2}$ Performance Measure}

Although the Sharpe ratio can be used to rank portfolios based on the actual performance, the interpretation of the numerical value of this ratio is difficult and challenging. If the Sharpe ratio for a random portfolio $p$ is greater than the Sharpe ratio for the market portfolio $m$, we know that the performance of the portfolio $p$ is better than the average market performance, however, it remains unknown to which extent the portfolio $p$ outperformed the market. In order to answer this question, the Nobel Prizewinning economist Franco Modigliani and his granddaughter Leah Modigliani developed the $M^{2}$ measure (also known as Modigliani riskadjusted performance) based on the Sharpe ratio (Modigliani \& Modigliani, 1997).

The authors started from the idea to put on "equal footing" the overall risk of the 
standardne devijacije tržišnog portfolija $m$, izjednačavanje ukupnih rizika posmatranih portfolija se postiže uvođenjem leveridža, tj. pozajmljivanjem sredstava po bezrizičnoj kamatnoj stopi i ulaganjem pozajmljenih sredstava u portfolio $p$.

Udeo portfolija $p \quad \mathrm{u}$ novonastalom korigovanom portfoliju $p^{*}$ jednak je odnosu standardne devijacije portfolija $m$ i standardne devijacije portfolija $p\left(\frac{\sigma_{m}}{\sigma_{p}}\right)$.S druge strane, udeo bezrizične aktive u novonastalom korigovanom portfoliju $p^{*}$ se utvrđuje na osnovu izraza $\left(1-\frac{\sigma_{m}}{\sigma_{p}}\right)$. Imajući $\mathrm{u}$ vidu navedeno, prinos korigovanog portfolija $p^{*}$ se utvrđuje na sledeći način:

$$
r_{p^{*}}=\frac{\sigma_{m}}{\sigma_{p}} r_{p}+\left(1-\frac{\sigma_{m}}{\sigma_{p}}\right) r_{f}
$$

gde su:

$r_{p^{*}}$ - prinos korigovanog portfolija $p^{*}$,

$\frac{\sigma_{m}^{p}}{\sigma_{p_{*}}}$ - udeo portfolija $p \mathrm{u}$ korigovanom portfoliju $p^{p_{*}}$,

$r_{p}$ - prinos portfolija $p$,

$\left(1-\frac{\sigma_{m}}{\sigma_{p}}\right)$ - udeo bezrizične aktive u korigovanom portfoliju $p^{*}$,

$r_{f}$ - prinos bezrizične aktive.

Konačno, kada se od prinosa korigovanog portfolija $\left(r_{p^{*}}\right)$ oduzme prinos tržišnog portfolija $\left(r_{m}\right)$, dobija se $M^{2}$ mera performansi portfolija:

$$
M^{2}=r_{p^{*}}-r_{m} .
$$

Dakle, $M^{2}$ mera performansi portfolija predstavlja razliku između stopa prinosa korigovanog i tržišnog portfolija, pod uslovom jednakosti standardnih devijacija njihovih prinosa. Drugim rečima, $M^{2}$ mera performansi portfolija je jednaka razlici između prinosa koji bi portfolio ostvario ukoliko bi imao isti nivo ukupnog rizika kao i tržišni indeks, i tržišnog prinosa.

Pored navedenog, $M^{2}$ mera performansi portfolija $p$ se može izraziti i kao razlika između Šarpovog indeksa za portfolio $p$ i Šarpovog indeksa za tržišni portfolio $m$, pomnožena standardnom devijacijom tržišnog prinosa (Francis \& Kim, 2013):

$$
M^{2}=\left(S_{p}-S_{m}\right) \sigma_{m} .
$$

Pošto je standardna devijacija uvek pozitivan broj, zaključuje se da će $M^{2}$ mera performansi portfolija $p$ biti pozitivna uvek kada je Šarpov indeks za portfolio $p$ veći od Šarpovog indeksa za tržišni portfolio $m$, odnosno, negativna uvek kada je Šarpov indeks za portfolio $p$ manji od Šarpovog indeksa za tržišni portfolio $m$.

Grafički prikazano $M^{2}$ mera performansi portfolija $p$ predstavlja vertikalno odstojanje pozicije korigovanog portfolija $p^{*}$ od pozicije tržišnog portfolija $m$ (Slika 1 ).

Slika 1: Grafički prikaz $M^{2}$ mere performansi

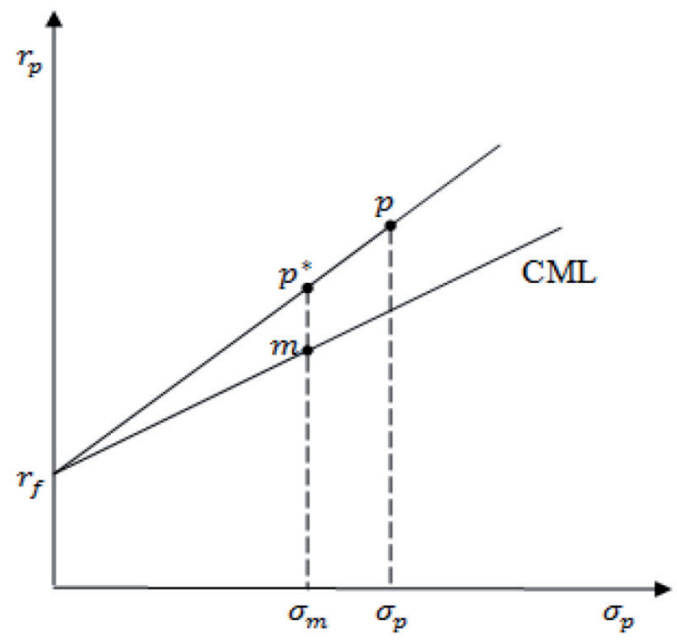

Izvor: Francis \& Kim, 2013

Poređenje performansi portfolija $p$ sa performansama tržišnog portfolija $m$ zahteva izjednačavanje njihovih ukupnih rizika. Stoga se rizičniji portfolio $p$ kombinuje sa bezrizičnom aktivom sve dok se standardna devijacija korigovanog portfolija $\left(\sigma_{p^{*}}\right)$ ne izjednači sa standardnom devijacijom tržišnog portfolija $\left(\sigma_{m}\right)$ (Slika 1). Vertikalno rastojanje od tačke $p^{*}$ do tačke $m$ predstavlja razliku između prinosa korigovanog portfolija $\left(r_{p^{*}}\right)$ i prinosa tržišnog portfolija $\left(r_{m}\right)$, odnosno, predstavlja $M^{2}$ meru performansi portfolija $p$, koja pokazuje za koliko procenata je portfolio $p$ uspeo da nadmaši tržište.

\section{$T^{2}$ mera performansi}

Poput Šarpovog indeksa i Trejnorov indeks je pogodan za rangiranje portfolija prema ostvarenim performansama, ali tumačenje numeričke vrednosti ovog indeksa ostaje izazov. Ukoliko je Trejnorov indeks za proizvoljni 
portfolio $p$ with the overall risk of the market portfolio $m$ in order to be able to compare the performance of the mentioned portfolios by simply comparing their returns. Equating the overall risk of the portfolio $p$ with the overall market risk requires the mixing of the portfolio $p$ with the risk-free assets or the introduction of the leverage. If the standard deviation of the portfolio $p$ is greater than the standard deviation of the market portfolio $m$, equating of the overall risks of the mentioned portfolios can be achieved by mixing the portfolio $p$ with the risk-free assets. However, if the standard deviation of the portfolio $p$ is smaller than the standard deviation of the market portfolio $m$, equating of the overall risks of the observed portfolios is achieved by introducing leverage, i.e. by borrowing money at the risk-free rate and investing the borrowed money in the portfolio $p$.

The share of the portfolio $p$ in the newly constructed adjusted portfolio $p^{*}$ is equal to the ratio of the standard deviation of the portfolio $m$ to the standard deviation of the portfolio $p\left(\frac{\sigma_{m}}{\sigma_{p}}\right)$. On the other hand, the proportion of the risk-free assets in the newly constructed adjusted portfolio $p^{*}$ is determined by using the formula $\left(1-\frac{\sigma_{m}}{\sigma_{p}}\right)$. Considering the above, the risk-adjusted return of the portfolio $p^{*}$ is determined as follows:

$$
r_{p^{*}}=\frac{\sigma_{m}}{\sigma_{p}} r_{p}+\left(1-\frac{\sigma_{m}}{\sigma_{p}}\right) r_{f}
$$

where:

$r_{p_{*}^{*}}$ - denotes the return of the adjusted portfolio $p^{*}$,

$\frac{\sigma_{m}}{\sigma_{p}}$ - denotes the share of the portfolio $p$ in the newly constructed adjusted portfolio $p^{*}$,

$r_{p}$ - denotes the return of the portfolio $p$, $\left(\begin{array}{c}p \\ 1-\frac{\sigma_{m}}{\sigma_{p}}\end{array}\right)$ - denotes the proportion of the riskfree assets in the newly constructed adjusted portfolio $p^{*}$,

$r_{f}$ - denotes the return on the risk-free assets.

Finally, when the return of the market portfolio $\left(r_{m}\right)$ is subtracted from the return of the adjusted portfolio $\left(r_{p^{*}}\right)$ we get the $M^{2}$ portfolio performance measure:

$$
M^{2}=r_{p^{*}}-r_{m} .
$$

Thus, the $M^{2}$ portfolio performance measure represents the difference between the adjusted and the market portfolio rates of return, provided that the standard deviations of their returns are equal. In other words, the $M^{2}$ portfolio performance measure equals the difference between the return a particular portfolio would achieve (if it had the same level of the overall risk as the market index) and the market return.

In addition, the $M^{2}$ performance measure of the portfolio $p$ can be denoted as the difference between the Sharpe ratio for the portfolio $p$ and the Sharpe ratio for the market portfolio $m$, multiplied by the standard deviation of the market return (Francis \& Kim, 2013):

$$
M^{2}=\left(S_{p}-S_{m}\right) \sigma_{m} .
$$

Since the standard deviation is always a positive number, it can be concluded that the $M^{2}$ performance measure of the portfolio $p$ will be positive in all cases where the Sharpe ratio of the portfolio $p$ is greater than the Sharpe ratio for the market portfolio $m$, and vice versa, it will always be negative when the Sharpe ratio for the portfolio $p$ is smaller than the Sharpe ratio for the market portfolio $m$.

In terms of a graphical representation, the $M^{2}$ performance measure of the portfolio $p$ represents the vertical distance between the position of the adjusted portfolio $p^{*}$ and the position of the market portfolio $m$ (Figure 1).

Figure 1: Illustration of the $M^{2}$ performance measure

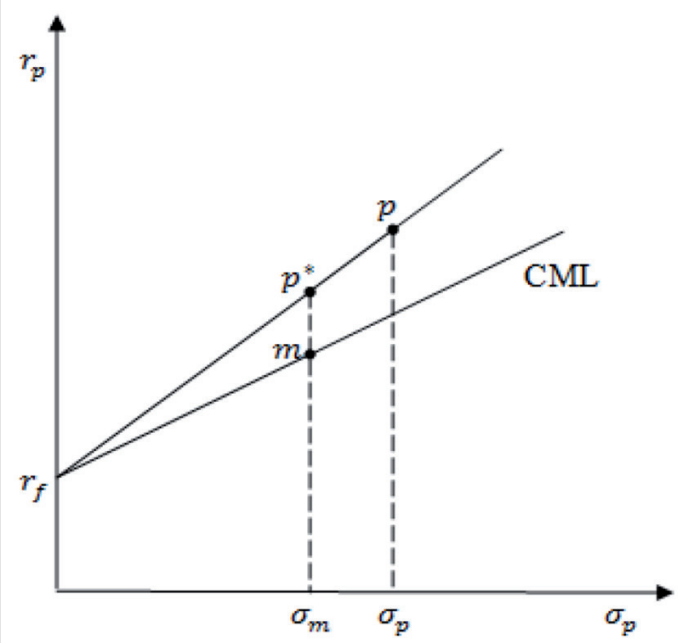

Source: Francis \& Kim, 2013 
portfolio $p$ veći od Trejnorovog indeksa za tržišni portfolio $m$, performanse portfolija $p$ su bolje od prosečnih tržišnih performansi. Međutim, prilikom uporedne analize performansi dva portfolija na osnovu vrednosti Trejnorovog indeksa ostaje nepoznato za koliko su performanse jednog portfolija bolje ili lošije od performansi drugog portfolija. U cilju otklanjanja navedenog nedostatka i lakšeg tumačenja numeričke vrednosti Trejnorovog indeksa uvedena je nova mera performansi portfolija u finansijskoj literaturi poznata kao $T^{2}$ mera performansi ili Trejnor na kvadrat mera performansi.

$\mathrm{U}$ osnovi $T^{2}$ mere performansi portfolija nalazi se ideja izjednačavanja sistemskog rizika portfolija $p$ sa sistemskim rizikom tržišnog portfolija $m$. Na ovaj način omogućeno je poređenje performansi portfolija jednostavnim poređenjem njihovih dodatnih prinosa. Izjednačavanje sistemskog rizika portfolija $p$ sa sistemskim rizikom tržišnog portfolija $m$ ostvaruje se kreiranjem korigovanog portfolija $p^{*}$, nastalog kombinovanjem portfolija $p$ sa bezrizičnom aktivom (ukoliko je beta koeficijent portfolija $p$ veći od beta koeficijenta tržišnog portfolija $m$ ) ili pak uvođenjem leveridža (ukoliko je beta koeficijent portfolija $p$ manji od beta koeficijenta tržišnog portfolija $m$ ).

Budući da je dodatni prinos bezrizične aktive jednak nuli $\left(R_{f}=0\right)$, dodatni prinos korigovanog portfolija $p^{*}\left(R_{p^{*}}\right)$ se utvrđuje na osnovu sledeće formule (Bodie i saradnici, 2009):

$$
R_{p^{*}}=w R_{p}
$$

gde su:

$w$ - udeo portfolija $p \mathrm{u}$ korigovanom portfoliju $p^{*}$,

$R_{p}$ - dodatni prinos portfolija $p$.

Udeo portfolija $p$ u korigovanom portfoliju $p^{*}$ se utvrđuje stavljanjem $\mathrm{u}$ odnos beta koeficijenta tržišnog portfolija $m$ i beta koeficijenta portfolija $p$ :

$$
w=\frac{\beta_{m}}{\beta_{p}}
$$

Imajući u vidu da je beta koeficijent tržišnog portfolija jednak jedinici, zaključuje se da je udeo portfolija $p$ u novonastalom korigovanom portfoliju $p^{*}$ jednak recipročnoj vrednosti njegovog beta koeficijenta:

$$
w=\frac{1}{\beta_{p}}
$$

Uvođenjem prethodnog izraza u jednačinu (7) dobija se:

$$
R_{p^{*}}=\frac{R_{p}}{\beta_{p}} .
$$

Konačno, oduzimanjem dodatnog prinosa tržišnog portfolija $\left(R_{m}\right)$ od dodatnog prinosa korigovanog portfolija $\left(R_{p^{*}}\right)$ dobija se $T^{2}$ mera performansi portfolija:

$$
T^{2}=R_{p^{*}}-R_{m} .
$$

Opisana mera performansi portfolija se može definisati kao razlika između dodatnog prinosa korigovanog portfolija i dodatnog prinosa tržišnog portfolija, pod uslovom jednakosti njihovih beta koeficijenata.

Grafički prikazano $T^{2}$ mera performansi portfolija $p$ predstavlja vertikalno odstojanje između pozicija korigovanog $\left(p^{*}\right)$ i tržišnog (m) portfolija (Slika 2).

Slika 2: Grafički prikaz $T^{2}$ mere performansi

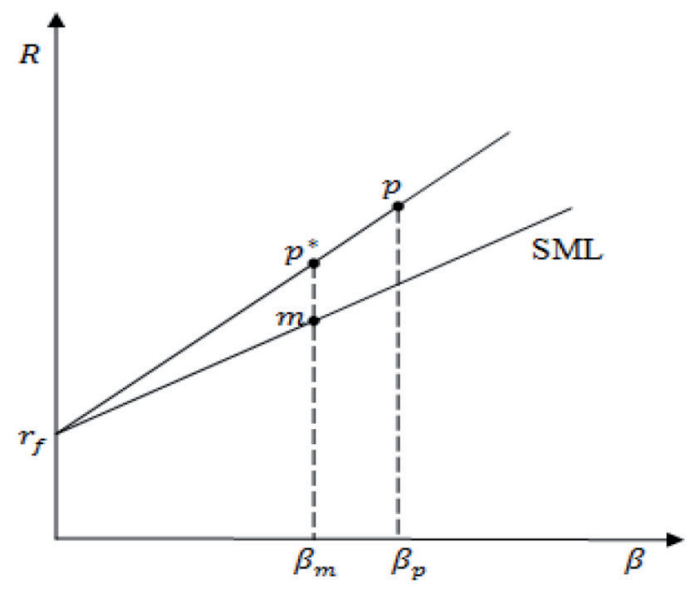

Izvor: Autor, na osnovu Bodie i saradnici, 2009

Portfolio $p$ se kombinuje sa bezrizičnom aktivom sve dok se beta koeficijent korigovanog portfolija $\left(\beta_{p^{*}}\right)$ ne izjednači sa beta koeficijentom tržišnog portfolija $\left(\beta_{m}\right)$. Izjednačavanjem beta koeficijenata stvoreni su uslovi za poređenje performansi portfolija putem poređenja njihovih dodatnih prinosa. Vertikalno rastojanje od tačke $p^{*}$ do tačke $m$ predstavlja razliku između dodatnog prinosa 
The comparison of the portfolio $p$ performance with that of the market portfolio $m$ requires the equation of their overall risks. Therefore, the risky portfolio $p$ is mixed with the risk-free asset until the standard deviation of the adjusted portfolio $\left(\sigma_{p^{*}}\right)$ equals the standard deviation of the market portfolio $\left(\sigma_{m}\right)$ (Figure $1)$. The vertical distance from the point $p^{*}$ to the point $m$ represents the difference between the return of the adjusted portfolio $\left(r_{p^{*}}\right)$ and the return of the market portfolio $\left(r_{m}\right)$, i.e. it represents the $M^{2}$ performance measure of the portfolio $p$, which indicates how much (in \%) the portfolio $p$ managed to outperform the market.

\section{$\boldsymbol{T}^{2}$ Performance Measure}

As well as the Sharpe ratio, the Treynor ratio is also suitable for portfolio ranking in terms of actual performance; however, the interpretation of the numerical value of this ratio remains a challenge. If the Treynor ratio of a random portfolio $p$ is greater than the Treynor ratio of the market portfolio $m$, this means that the performance of the portfolio $p$ is better than the average market performance. However, the comparative analysis of the performance of these two portfolios based on the value of the Treynor ratio does not offer the information about the extent to which the performance of one portfolio is better or worse than the performance of another portfolio. In order to eliminate this deficiency and facilitate the interpretation of the numerical value of the Treynor ratio, a new portfolio performance measure was introduced. In the reference literature this measure is known as the $T^{2}$ performance measure or the Treynor-square measure or simply the Treynor-squared.

The $T^{2}$ portfolio performance measure is developed based on the idea of equating the systemic risk of the portfolio $p$ and the systemic risk of the market portfolio $m$. In this way it is possible to compare the performance of different portfolios by simply comparing their excess returns. Equating the systemic risk of the portfolio $p$ with the systemic risk of the market portfolio $m$ is achieved by constructing the adjusted portfolio $p^{*}$. The portfolio $p^{*}$ is constructed by mixing the portfolio $p$ with the risk-free asset (if the beta coefficient of the portfolio $p$ is greater than the beta coefficient of the market portfolio $m$ ), or by introducing leverage (if the beta coefficient of the portfolio $p$ is smaller than the beta coefficient of the market portfolio $m$ ).

Since the excess return of the risk-free assets equals zero $\left(R_{f}=0\right)$, the excess return of the adjusted portfolio $p^{*}\left(R_{p^{*}}\right)$ is determined by applying the following formula (Bodie et al., 2009):

$$
R_{p^{*}}=w R_{p}
$$

where:

$w$ - denotes the share of the portfolio $p$ in the adjusted portfolio $p^{*}$,

$R_{p}$ - denotes the return of the portfolio $p$.

The share of the portfolio $p$ in the adjusted portfolio $p^{*}$ is determined by dividing the beta coefficient of the market portfolio $m$ by the beta coefficient of the portfolio $p$ :

$$
w=\frac{\beta_{m}}{\beta_{p}} .
$$

Considering that the beta coefficient of the market portfolio equals 1 , it is concluded that the share of the portfolio $p$ in the newly constructed portfolio $p^{*}$ equals the reciprocal value of its beta coefficient:

$$
w=\frac{1}{\beta_{p}} .
$$

By inserting the above expression in equation (7) we get:

$$
R_{p^{*}}=\frac{R_{p}}{\beta_{p}} .
$$

Finally, by subtracting the excess return of the market portfolio ( ) from the excess return of the adjusted portfolio $\left(R_{p^{*}}\right)$ we get the $T^{2}$ portfolio performance measure:

$$
T^{2}=R_{p^{*}}-R_{m}
$$

The described portfolio performance measure can be defined as the difference between the excess return of the adjusted portfolio and the excess return of the market portfolio, provided that their beta coefficients are equal.

In terms of graphical representation, the $T^{2}$ performance measure of the portfolio $p$ represents the vertical distance between the position of the adjusted portfolio $\left(p^{*}\right)$ and the market $(m)$ portfolio (Figure 2). 
korigovanog portfolija $\left(R_{p^{*}}\right)$ i dodatnog prinosa tržišnog portfolija $\left(R_{m}\right)$, odnosno, predstavlja $T^{2}$ meru performansi portfolija $p$.

\section{Treynor-Mazuy model}

Treynor i Mazuy (1966) su osmislili metod testiranja uspešnosti menadžera investicionih fondova $u$ predviđanju tržišnih fluktuacija. U nastojanju da utvrde da li menadžeri investicionih fondova poseduju sposobnost tržišnog tajminga i da li uspevaju da nadmaše tržište, autori su pošli od sledećeg pitanja: „postoje li dokazi da je promenljivost prinosa investicionih fondova (u smislu preuzetog rizika) u godinama rastućeg tržišta viša od volatilnosti prinosa investicionih fondova $\mathrm{u}$ godinama opadajućeg tržišta?". Potvrdan odgovor na ovo pitanje značio bi prisustvo, a odričan odsustvo sposobnosti tržišnog tajminga. Istražujući performanse 57 otvorenih investicionih fondova autori su samo u slučaju jednog investicionog fonda pronašli dokaze $u$ korist verovanja da menadžeri investicionih fondova poseduju sposobnost predviđanja tržišnih fluktuacija i uspevaju da nadmaše tržište.

Treynor i Mazuy (1966) se sa pravom smatraju pionirima $\mathrm{u}$ oblasti istraživanja sposobnosti tržišnog tajminga portfolio menadžera investicionih fondova. $\mathrm{Na}$ osnovu njihovih zapažanja iznetih 1966. godine u radu „Can Mutual Funds Outguess the Market", drugi istraživači su kvantitativno izrazili njihov model putem sledeće kvadratne regresije (Francis \& Kim, 2013):

$$
r_{p}-r_{f}=\alpha_{p}+\beta_{p}\left(r_{m}-r_{f}\right)+\gamma_{p}\left(r_{m}-r_{f}\right)^{2}+\varepsilon_{p},
$$

gde su:

$\alpha_{p}$ - mera selekcione sposobnosti portfolio menadžera,

$\gamma_{p}$ - mera sposobnosti tajminga tržišta, tj. koeficijent tržišnog tajminga,

$\varepsilon_{p}$ - slučajna greška (rezidual).

Nije teško zaključiti da su Treynor i Mazuy (1966) među prvima izvršili dekompoziciju ukupnih performansi investicionih fondova na performanse koje se pripisuju sposobnosti selekcije najboljih hartija od vrednosti i performanse koje se pripisuju sposobnosti tajminga tržišta. Oni su, u cilju ocene menadžerove sposobnosti tajminga tržišta, izvršili modifikaciju standardnog CAPM modela uvođenjem izraza $\gamma_{p}\left(r_{m}-r_{f}\right)^{2}$. Autori su naglasili da linearna regresija važi samo ako je beta koeficijent konstantan tokom vremena. Promene beta koeficijenta zahtevaju primenu kvadratne regresije, odnosno, uvođenje kvadrirane tržišne riziko premije, $\left(r_{m}-r_{f}\right)^{2}, \mathrm{u}$ jednačinu CAPM modela.

Treynor-Mazuy model, predstavljen jednačinom (12), meri sposobnost portfolio menadžera da pravovremeno prilagođava strukturu portfolija izmenjenim tržišnim okolnostima i nastupajućim tržišnim kretanjima. Tačnije, ovaj model meri sposobnost portfolio menadžera da menja strukturu portfolija u korist rizičnijih hartija od vrednosti neposredno pre rasta tržišta, odnosno, u korist manje rizičnih hartija od vrednosti neposredno pre pada tržišta. Dakle, zadatak portfolio menadžera je predviđanje nastupanja faze rastućeg ili pak faze opadajućeg tržišta i pravovremeno prilagođavanje strukture portfolija tim predviđanjima.

Kao mera sposobnosti tajminga tržišta $u$ Treynor-Mazuy modelu koristi se koeficijent tržišnog tajminga $\left(\gamma_{p}\right)$ :

- ukoliko je koeficijent tržišnog tajminga pozitivan $\left(\gamma_{p}>0\right)$ portfolio menadžer investicionog fonda pokazuje zavidnu sposobnost predviđanja tržišnih fluktuacija i pravovremenog reagovanja na iste,

- ukoliko je koeficijent tržišnog tajminga jednak nuli $\left(\gamma_{p}=0\right)$ portfolio menadžeru investicionog fonda nedostaje potrebna veština tajminga tržišta, a performanse fonda primarno zavise od selekcione sposobnosti portfolio menadžera,

- negativan koeficijent tržišnog tajminga $\left(\gamma_{p}<0\right)$ ukazuje ne samo na nedostatak sposobnosti tržišnog tajminga, već i na donošenje pogrešnih procena tržišnih kretanja i pogrešnih odluka o strukturi portfolija i visini beta koeficijenta portfolija. Pored vrednosti koeficijenta tržišnog tajminga, na prisustvo ili odsustvo sposobnosti tajminga tržišta ukazuje i oblik karakteristične linije investicionog fonda, tj. njen nagib $u$ uslovima opadajućeg i uslovima rastućeg tržišta:

- ukoliko je karakteristična linija konveksna prema $y$-osi portfolio menadžer investicionog fonda poseduje sposobnost tajminga tržišta (Slika 3), 
Figure 2: Illustration of the $T^{2}$ performance measure

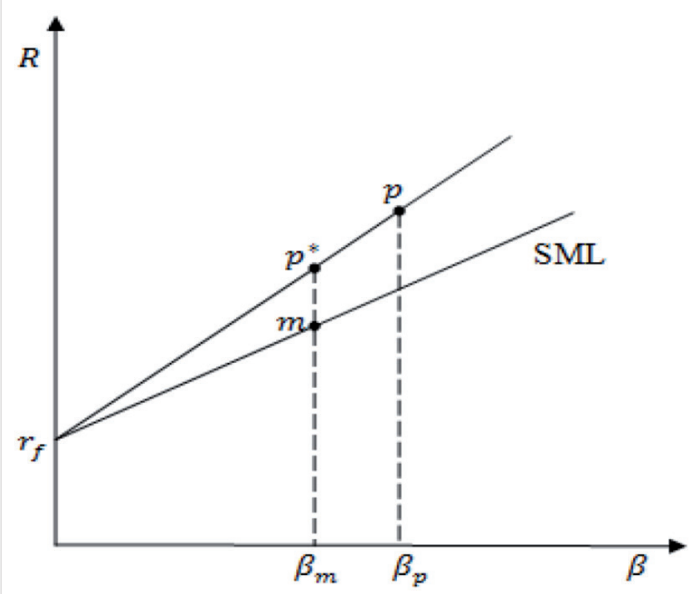

Source: Author, based on Bodie et al., 2009

The portfolio $p$ is mixed with the risk-free asset until the beta coefficient of the adjusted portfolio $\left(\beta_{p^{*}}\right)$ equals the beta coefficient of the market portfolio $\left(\beta_{m}\right)$. By making the beta coefficients even, it is possible to compare the performance of the mentioned portfolios by comparing their excessive returns. The vertical distance from the point $p^{*}$ to the point $m$ represents the difference between the excessive return of the adjusted portfolio $\left(R_{p^{*}}\right)$ and the excessive return of the market portfolio $\left(R_{m}\right)$, i.e. it represents the $T^{2}$ performance measure of the portfolio $p$.

\section{Treynor-Mazuy Model}

Treynor and Mazuy (1966) developed a method for testing the ability of mutual fund managers to anticipate market fluctuations. In an effort to determine whether the mutual fund managers possess the market timing skills and whether they are capable of outperforming the market, the authors started to build their model based on the following question: "Is there evidence that the fund's volatility (in terms of risk-taking) was higher in the years when the market did well than in the years when the market did badly?". An affirmative answer to this question would imply the presence of the market-timing ability, and vice versa, while a negative answer would point to a lack of the market-timing ability. By analyzing the performance records of 57 openend mutual funds, the authors found only one case that supported the opinion that mutual fund managers had the ability to anticipate the market fluctuations and succeeded in outguessing the market.

Treynor and Mazuy (1966) are rightfully considered the pioneers in the field of researching the market-timing ability of portfolio managers managing mutual funds. Based on their observations presented in their paper entitled "Can Mutual Funds Outguess the Market" published in 1966, other researchers were able to translate their model assumptions into the following quadratic regression (Francis \& Kim, 2013):

$r_{p}-r_{f}=\alpha_{p}+\beta_{p}\left(r_{m}-r_{f}\right)+\gamma_{p}\left(r_{m}-r_{f}\right)^{2}+\varepsilon_{p}$

where:

$\alpha_{p}$ - denotes the selection ability of a portfolio manager,

$\gamma_{p}$ - denotes the parameter measuring the market timing performance, i.e. the market timing coefficient,

$\varepsilon_{p}$ - denotes the random error (residual).

It is not difficult to conclude that Treynor and Mazuy (1966) were among the first scholars who performed the decomposition of the overall performance of mutual funds to the components that concern the ability of portfolio managers to select securities and those that concern the market timing ability. The mentioned authors modified the standard CAPM model by introducing the expression $\gamma_{p}\left(r_{m}-r_{f}\right)^{2}$ in order to assess the market-timing ability of portfolio managers. They pointed out that the linear regression is valid only if the beta coefficient is constant over time. The changes in the beta coefficient require the application of a quadratic regression, i.e. inserting of the squared market risk premium, $\left(r_{m}-r_{f}\right)^{2}$, into the CAPM equation.

The Treynor-Mazuy model, as represented by the equation (12), measures the ability of portfolio managers to timely adjust the portfolio composition to the major market turns and future market movements. Namely, this model measures the ability of portfolio managers to adjust the portfolio composition by opting for riskier securities immediately prior to the onset of the up market period, or by opting for less risky securities just before the down market period. Therefore, the task of the 
- ukoliko je karakteristična linija prava linija portfolio menadžer investicionog fonda ne poseduje sposobnost tajminga tržišta (Slika 4),

- ukoliko je karakteristična linija konveksna prema $x$-osi tajming tržišta je loš, a donete odluke pogrešne i neusklađene sa trenutnom situacijom na tržištu (Slika 5).

Na Slici 3 grafički je prikazan TreynorMazuy model za slučaj pozitivnog koeficijenta tržišnog tajminga $\left(\gamma_{p}>0\right)$.

Slika 3: Grafički prikaz Treynor-Mazuy modela za slučaj $\gamma_{p}>0$

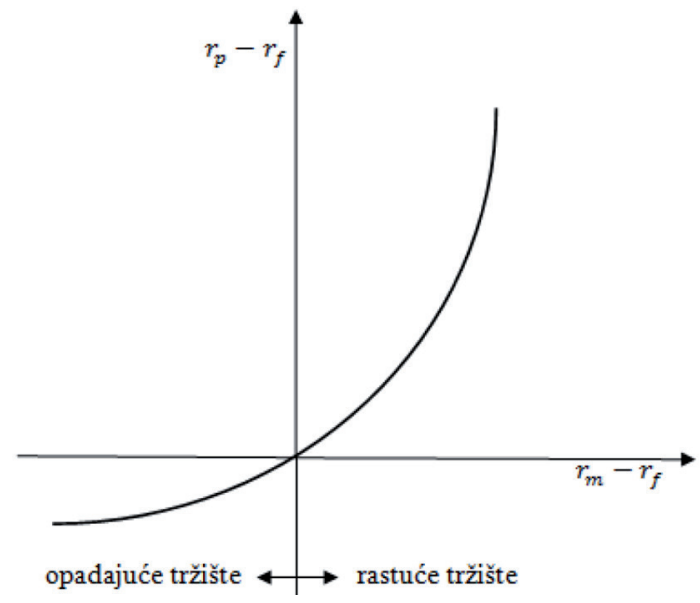

Izvor: Francis \& Kim, 2013

Treynor-Mazuy model za slučaj pozitivnog koeficijenta tržišnog tajminga grafički se predstavlja karakterističnom linijom konveksnom prema $y$-osi. Strm nagib karakteristične linije i visok beta koeficijent portfolija u uslovima rastućeg tržišta, kao i blag nagib karakteristične linije i nizak beta koeficijent portfolija u uslovima opadajućeg tržišta ukazuju na prisustvo sposobnosti tajminga tržišta. Tržište se smatra rastućim ukoliko je tržišna stopa prinosa viša od bezrizične stope prinosa $\left(r_{m}>r_{f}\right)$, odnosno, ukoliko je razlika između ove dve stope pozitivna $\left(r_{m}-r_{f}>0\right)$. Obrnuto, tržište se smatra opadajućim ukoliko je tržišna stopa prinosa niža od bezrizične stope prinosa $\left(r_{m}<r_{f}\right)$, tj. ukoliko je razlika između ove dve stope negativna $\left(r_{m}-r_{f}<0\right)$.

Konveksnost karakteristične linije prema y-osi govori da u uslovima rastućeg tržišta raste nagib karakteristične linije, dok u uslovima opadajućeg tržišta opada i nagib ove linije. Pre nego što tržište uđe $u$ fazu rasta uspešan portfolio menadžer menja strukturu portfolija u korist rizične aktive. Na ovaj način povećava se tržišna izloženost portfolija i maksimira potencijalni dobitak. $S$ druge strane, pre nego što tržište uđe $u$ fazu pada uspešan portfolio menadžer menja strukturu portfolija u korist sigurne (manje rizične) aktive. Na ovaj način smanjuje se tržišna izloženost portfolija i minimizira potencijalni gubitak. Za portfolio menadžera koji povećava betu portfolija neposredno pre rasta tržišta i smanjuje betu portfolija neposredno pre pada tržišta se kaže da poseduje sposobnost tajminga tržišta.

$\mathrm{Na}$ narednoj slici grafički je prikazan Treynor-Mazuy model za slučaj nultog koeficijenta tržišnog tajminga $\left(\gamma_{p}=0\right)$.

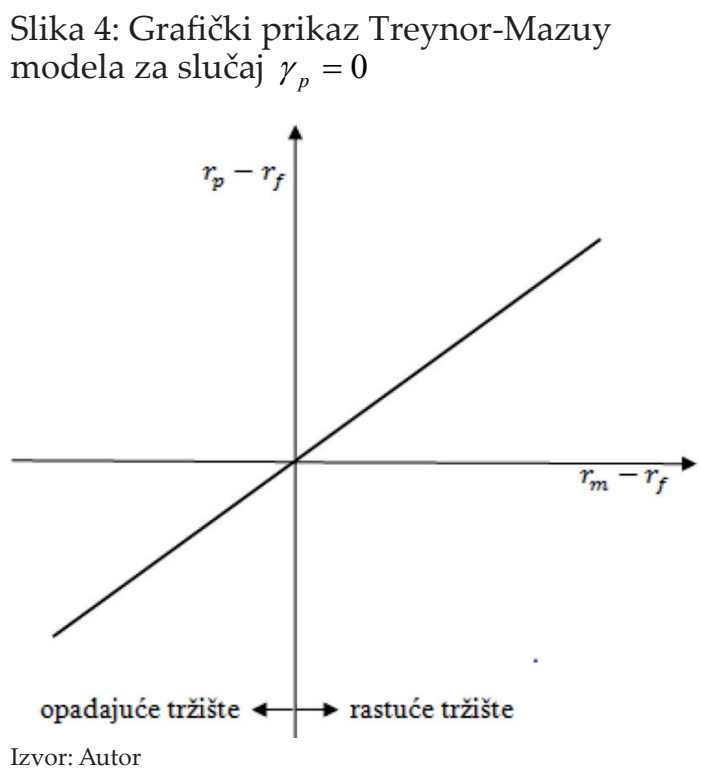

Treynor-Mazuy model za slučaj nultog koeficijenta tržišnog tajminga grafički se predstavlja pravom karakterističnom linijom. Jednak (nepromenjen) nagib karakteristične linije i jednak beta koeficijent portfolija kako u uslovima rastućeg tržišta, tako i u uslovima opadajućeg tržišta ukazuju na odsustvo sposobnosti tajminga tržišta. Portfolio menadžer investicionog fonda ne prilagođava strukturu portfolija izmenjenim tržišnim okolnostima i predviđenim tržišnim kretanjima. U odsustvu sposobnosti tajminga tržišta performanse investicionog fonda primarno zavise od selekcione sposobnosti portfolio menadžera, odnosno, sposobnosti izbora najboljih hartija od vrednosti pri datom nivou rizika.

Konačno, u slučaju negativnog koeficijenta tržišnog tajminga $\left(\gamma_{p}<0\right)$ Treynor-Mazuy model se grafički predstavlja karakterističnom linijom konveksnom prema $x$-osi (Slika 5): 
portfolio manager is to anticipate the onset of the up market or the down market periods and to timely adjust the portfolio composition.

In terms of the Treynor-Mazuy model, the market timing coefficient $\left(\gamma_{p}\right)$ is used as a parameter which measures the market timing performance:

- If the market timing coefficient is positive $\left(\gamma_{p}>0\right)$, this means that a portfolio manager has significant ability to predict the market fluctuations and to address them in a timely manner,

- If the market timing coefficient equals zero $\left(\gamma_{p}=0\right)$, the portfolio manager of some mutual fund lacks the market-timing ability, and it should be noted that the portfolio performance and its elements primarily depend on the manager's selection ability,

- If the market timing coefficient is negative $\left(\gamma_{p}<0\right)$, this points not only to the manager's lack of timing ability, but also to the fact that the manager made some wrong decisions in terms of the portfolio structure and the value of the portfolio's beta coefficient, as well as that he/she was not able to appropriately anticipate the market movements.

In addition to the market timing coefficient values, the presence or the lack of the market timing ability is indicated by the shape of the characteristic line, i.e. its slope in up and/or down market conditions:

- If the characteristic line is convex to the $y$-axis, the portfolio manager of a mutual fund has the sufficient market timing ability (Figure 3),

- If the characteristic line is a straight line, the portfolio manager of a mutual fund lacks the market timing ability (Figure 4),

- If the characteristic line is convex to the $x$-axis the market timing is poor, and the decisions taken are the wrong ones and are not in line with the ongoing market situation (Figure 5).

Figure 3 illustrates the Treynor-Mazuy model when the market timing coefficient has a positive value $\left(\gamma_{p}>0\right)$.
Figure 3: Illustration of the Treynor-Mazuy model where $\gamma_{p}>0$

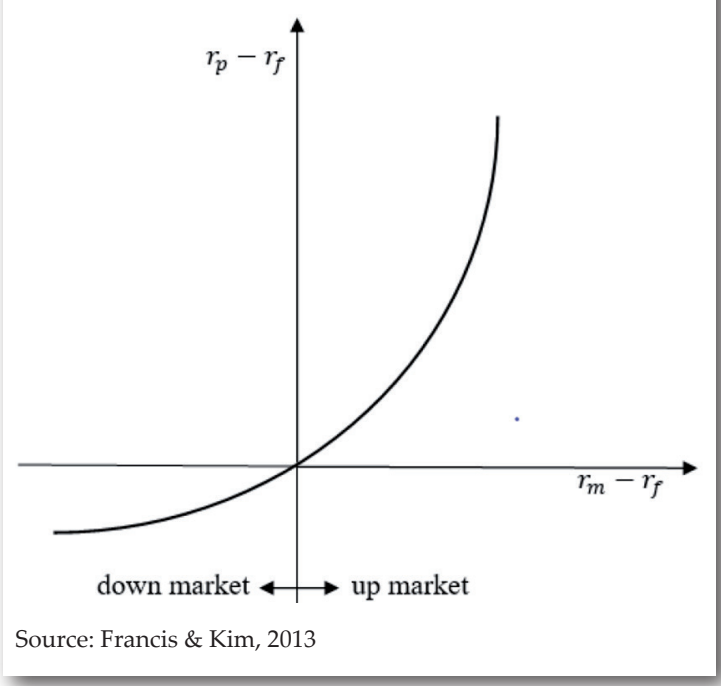

The Treynor-Mazuy model in the case of a positive market timing coefficient is graphically represented by a characteristic line, which is convex to the y-axis. The steep slope of the characteristic line and the high beta coefficient of the concerned portfolio during the up market conditions, as well as the moderate slope of the characteristic line and the low beta coefficient during the down market conditions, indicate the presence of the market timing ability. The market is considered to be increasing if the market return rate is higher than the riskfree return rate $\left(r_{m}>r_{f}\right)$, i.e. if the difference between these two rates is a positive number $\left(r_{m}-r_{f}>0\right)$. On the other hand, the market is considered to be in decline if the market return rate is lower than the risk-free return rate $\left(r_{m}<r_{f}\right)$, i.e. if the difference between these two rates is a negative number $\left(r_{m}-r_{f}<0\right)$.

Convexity of the characteristic line towards the $y$-axis indicates that in terms of the up market, the slope of the characteristic line increases, while in terms of the down market conditions, the slope of this line decreases. Before the market begins to grow, a successful portfolio manager changes the structure of the portfolio in favor of risky assets. In this way, the market exposure of the portfolio is increased and the potential gains are maximized. On the other hand, before the market enters a period of decline, a successful portfolio manager changes the structure of the portfolio in favor of safe (less risky) assets. This reduces the market exposure of the portfolio and minimizes the potential 


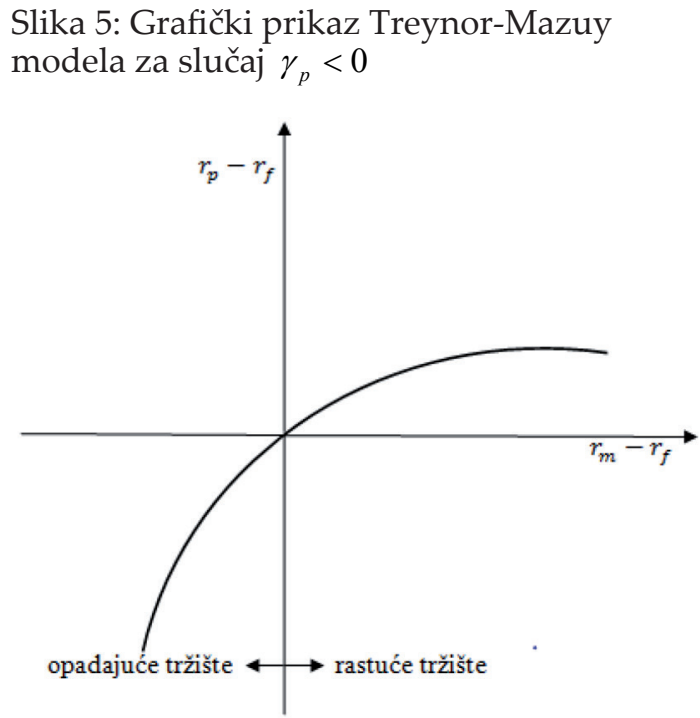

Izvor: Autor

Konveksnost karakteristične linije prema $x$-osi znači da u uslovima rastućeg tržišta opada nagib karakteristične linije, dok u uslovima opadajućeg tržišta raste nagib ove linije. Blag nagib karakteristične linije i nizak beta koeficijent portfolija u uslovima rastućeg tržišta, kao i strm nagib karakteristične linije i visok beta koeficijent portfolija u uslovima opadajućeg tržišta ukazuju na pogrešan tajming tržišta.

Portfolio menadžer donosi pogrešne odluke neuskađene sa nastupajućim tržišnim kretanjima. Pre nego što tržište uđe u fazu rasta portfolio menadžer smanjuje betu portfolija i samim tim minimizira potencijalni dobitak. S druge strane, pre nego što tržište uđe u fazu pada portfolio menadžer povećava betu portfolija i na ovaj način maksimira potencijalni gubitak. Za portfolio menadžera koji smanjuje betu portfolija neposredno pre rasta tržišta i povećava betu portfolija neposredno pre pada tržišta se kaže da donosi odluke potpuno suprotne od odluka uspešnog portfolio menadžera.

\section{Henriksson-Merton model}

Alternativni model ocene menadžerove sposobnosti tajminga tržišta razvili su Henriksson i Merton (1981). HenrikssonMerton model se kvantitativno izražava putem sledeće formule (Francis \& Kim, 2013):

$$
r_{p}-r_{f}=\alpha_{p}+\beta_{p}\left(r_{m}-r_{f}\right)+\varphi_{p} D\left(r_{m}-r_{f}\right)+\varepsilon_{p^{\prime}}
$$

gde su: $\varphi_{p}$ - koeficijent tržišnog tajminga,

$D$ - veštačka varijabla takva da je:

$$
D=\left\{\begin{array}{lcl}
0 & z a & r_{m}>r_{f} \\
-1 & z a & r_{m}<r_{f}
\end{array}\right.
$$

Različite vrednosti izraza $r_{m}-r_{f}$ rezultiraju sledećim modifikacijama jednačine (13) (Sharpe i saradnici, 1995):

$r_{m}-r_{f}>0 \quad \rightarrow \quad r_{p}-r_{f}=\alpha_{p}+\beta_{p}\left(r_{m}-r_{f}\right)+\varepsilon_{p}$

$$
\begin{aligned}
& r_{m}-r_{f}=0 \quad \rightarrow \quad r_{p}-r_{f}=\alpha_{p}+\varepsilon_{p} \\
& r_{m}-r_{f}<0 \quad \rightarrow \quad r_{p}-r_{f}=\alpha_{p}+\left(\beta_{p}-\varphi_{p}\right)\left(r_{m}-r_{f}\right)+\varepsilon_{p}
\end{aligned}
$$

Važno je primetiti da parametar $\beta_{p}$ iz jednačine (15) predstavlja beta koeficijent portfolija u uslovima rastućeg tržišta, dok parametar $\left(\beta_{p}-\varphi_{p}\right)$ izjednačine (17) predstavlja beta koeficijent portfolija u uslovima opadajućeg tržišta. Razlika između beta koeficijenta portfolija u uslovima rastućeg tržišta $\left(\beta_{p}\right)$ i beta koeficijenta portfolija u uslovima opadajućeg tržišta $\left(\beta_{p}-\varphi_{p}\right)$ je parametar $\varphi_{p}$ :

$$
\beta_{p}-\left(\beta_{p}-\varphi_{p}\right)=\varphi_{p}
$$

Budući da prisustvo sposobnosti tajminga tržišta zahteva da beta koeficijent portfolija u uslovima rastućeg tržišta bude veći od beta koeficijenta portfolija u uslovima opadajućeg tržišta, parametar $\varphi_{p}$ mora biti pozitivan.

$\mathrm{Na}$ osnovu navedenog zaključuje se da se $\mathrm{u}$ Henriksson-Merton modelu kao mera sposobnosti tajminga tržišta koristi koeficijent tržišnog tajminga $\left(\varphi_{p}\right)$. Tumačenje vrednosti ovog koeficijenta $\mathrm{u}$ potpunosti odgovara tumačenju vrednosti koeficijenta tržišnog tajminga $\left(\gamma_{p}\right)$ iz Treynor-Mazuy modela:

- pozitivan koeficijent tržišnog tajminga $\left(\varphi_{p}>0\right)$ ukazuje da portfolio menadžer investicionog fonda poseduje sposobnost tajminga tržišta,

- nulti koeficijent tržišnog tajminga $\left(\varphi_{p}=0\right)$ ukazuje da portfolio menadžer investicionog fonda ne poseduje sposobnost tajminga tržišta,

- negativan koeficijent tržišnog tajminga $\left(\varphi_{p}<0\right)$ ukazuje da portfolio menadžer investicionog fonda pogrešno procenjuje 
losses. A portfolio manager who increases the portfolio's beta just before the onset of the up market phase and reduces the portfolio's beta just before the down market phase, is said to possess the market timing ability.

The Figure below illustrates the TreynorMazuy model when the market timing coefficient equals zero $\left(\gamma_{p}=0\right)$.

Figure 4: Illustration of the Treynor-Mazuy model where $\gamma_{p}=0$

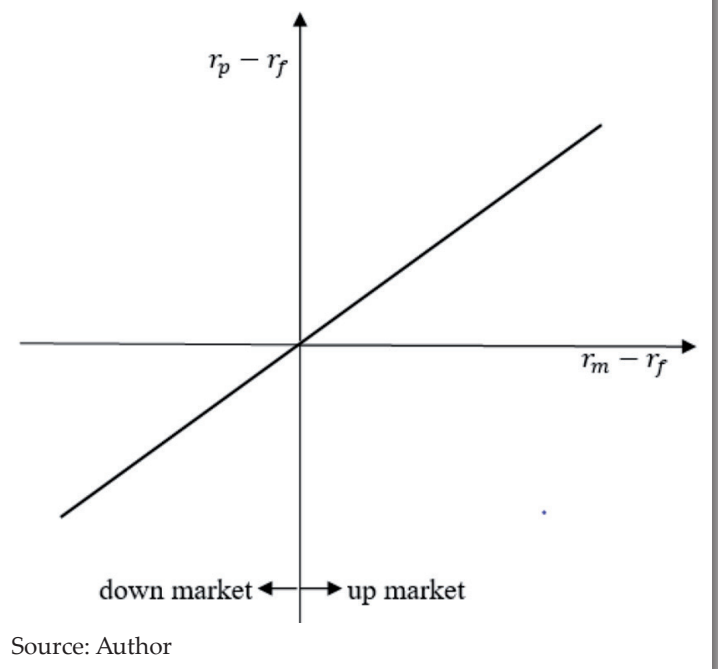

The Treynor-Mazuy model in the case when the market timing coefficient equals zero is illustrated as a straight characteristic line. The same (unchanged) slope of the characteristic line and the same value of the portfolio's beta coefficient in the up market conditions, as well as in the down market conditions, indicate a lack of the market timing ability. A portfolio manager in a mutual fund is unable to adjust the structure of the portfolio to the changed market conditions and anticipated market movements. In this case, when there is a lack of the timing ability, the performance of the mutual fund primarily depends on the selection ability of the portfolio manager, i.e. the ability to select the best securities at a given level of risk.

Finally, in the case when the market timing coefficient has a negative value $\left(\gamma_{p}<0\right)$ the Treynor-Mazuy model is graphically represented as a characteristic line which is convex to the $\mathrm{x}$-axis (Figure 5):
Figure 5: Illustration of the Treynor-Mazuy where $\gamma_{p}<0$

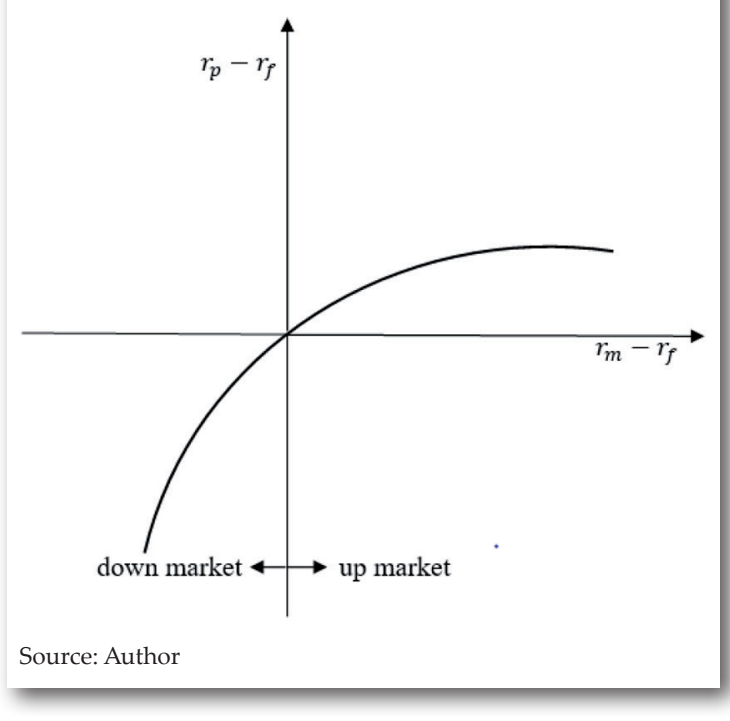

Convexity of the characteristic line towards the $x$-axis means that, in the up market conditions, the slope of the characteristic line decreases, while in the down market conditions, the slope of this line increases. The mild slope of the characteristic line and the low beta coefficient of the portfolio in the up market conditions, as well as the steep slope of the characteristic line and the high beta coefficient of the portfolio in the down market conditions, indicate the bad market timing.

In this case, the portfolio manager makes the wrong decisions which are not in keeping with the forthcoming market movements. Before the market enters a phase of growth, the portfolio manager reduces the beta of the portfolio and thus minimizes the potential gain. On the other hand, before the market enters a phase of decline, the portfolio manager increases the beta of the portfolio and, thereby, maximizes the potential loss. The portfolio manager who reduces the beta of the portfolio just before the up market period and increases the beta of the portfolio just before the down market is said to make the completely opposite decisions to those of a successful portfolio manager.

\section{Henriksson-Merton Model}

Henriksson and Merton developed an alternative model in order to evaluate the market timing abilities of fund managers (1981). The Henriksson-Merton model is quantitatively expressed by the following formula (Francis \& Kim, 2013): 
tržišna kretanja i donosi pogrešne odluke o strukturi portfolija i visini beta koeficijenta portfolija.

Henriksson-Merton model se grafički predstavlja pomoću dve odvojene prave karakteristične linije: karakteristične linije u uslovima rastućeg tržišta i karakteristične linije u uslovima opadajućeg tržišta. Karakterističnoj liniji u uslovima rastućeg tržišta odgovara jednačina (15), dok karakterističnoj liniji u uslovima opadajućeg tržišta odgovara jednačina (17). Analizom nagiba ovih linija mogu se doneti zaključci o prisustvu ili odsustvu sposobnosti tajminga tržišta:

- ukoliko je karakteristična linija u uslovima rastućeg tržišta strmog nagiba, a karakteristična linija u uslovima opadajućeg tržišta blagog nagiba portfolio menadžer investicionog fonda poseduje sposobnost tajminga tržišta (Slika 6),

- ukoliko su obe karakteristične linijejednakog nagiba pod uglom od 45 stepeni portfolio menadžer investicionog fonda ne poseduje sposobnost tajminga tržišta (Slika 7),

- ukoliko je karakteristična linija u uslovima rastućeg tržišta blagog nagiba, a karakteristična linija u uslovima opadajućeg tržišta strmog nagiba tajming tržišta je loš, a donete odluke pogrešne i neusklađene sa trenutnom situacijom na tržištu (Slika 8).

Na Slici 6 grafički je prikazan HenrikssonMerton model za slučaj pozitivnog koeficijenta tržišnog tajminga $\left(\varphi_{p}>0\right)$.

Slika 6: Grafički prikaz Henriksson-Merton modela za slučaj $\varphi_{p}>0$

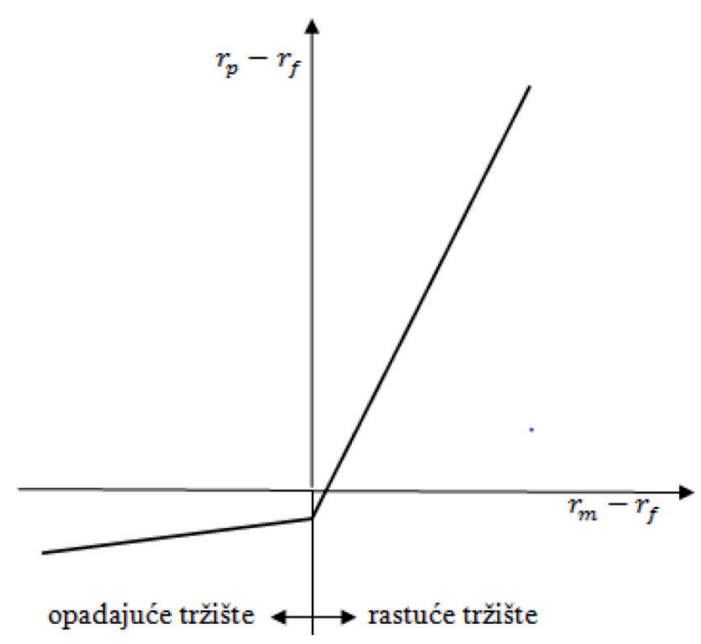

Izvor: Autor, na osnovu Sharpe i saradnici, 1995
Henriksson-Merton model za slučaj pozitivnog koeficijenta tržišnog tajminga podrazumeva strm nagib karakteristične linije $\mathrm{u}$ fazi rastućeg tržišta i blag nagib karakteristične linije u fazi opadajućeg tržišta. Strm nagib karakteristične linije u fazi rastućeg tržišta ukazuje na visok beta koeficijent i visoku tržišnu izloženost portfolija, dok blag nagib karakteristične linije u fazi opadajućeg tržišta ukazuje na nizak beta koeficijent i nisku tržišnu izloženost portfolija. Visoka tržišna izloženost portfolija u uslovima rastućeg tržišta rezultira natprosečnim prinosima, dok niska tržišna izloženost portfolija u uslovima opadajućeg tržišta rezultira ispodprosečnim gubicima. Natprosečni prinosi ostvareni u uslovima rastućeg tržišta i ispodprosečni gubici postignuti u uslovima opadajućeg tržišta potvrđuju prisustvo sposobnosti tržišnog tajminga od strane portfolio menadžera investicionih fondova.

$\mathrm{Na}$ narednoj slici grafički je prikazan Henriksson-Merton model za slučaj nultog koeficijenta tržišnog tajminga $\left(\varphi_{p}=0\right)$.

Slika 7: Grafički prikaz Henriksson-Merton modela za slučaj $\varphi_{p}=0$

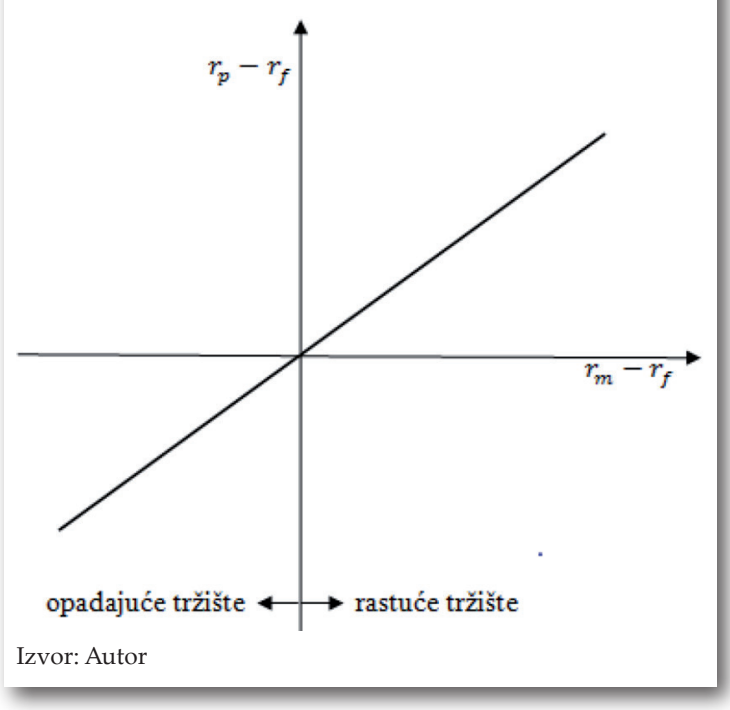

Razlika u odnosu na grafički prikaz TreynorMazuy modela za slučaj nultog koeficijenta tržišnog tajminga $\left(\gamma_{i}=0\right)$ se ogleda u činjenici da grafički prikaz Henriksson-Merton modela podrazumeva upotrebu dve karakteristične linije. Prikazani jednaki nagibi karakterističnih linija ukazuju na odsustvo sposobnosti predviđanja tržišnih fluktuacija i pravovremene izmene strukture portfolija. Portfolio menadžer 
$r_{p}-r_{f}=\alpha_{p}+\beta_{p}\left(r_{m}-r_{f}\right)+\varphi_{p} D\left(r_{m}-r_{f}\right)+\varepsilon_{p}$,

where:

$\varphi_{p}$ - denotes the market timing coefficient,

$D$ - denotes the dummy variable, therefore:

$$
D=\left\{\begin{array}{lll}
0 & z a & r_{m}>r_{f} \\
-1 & z a & r_{m}<r_{f}
\end{array}\right.
$$

The different values of the expression $r_{m}-r_{f}$ result in the following modifications of the equation (13) (Sharpe et al., 1995):

$$
r_{m}-r_{f}>0 \quad \rightarrow \quad r_{p}-r_{f}=\alpha_{p}+\beta_{p}\left(r_{m}-r_{f}\right)+\varepsilon_{p}
$$

$$
r_{m}-r_{f}=0 \quad \rightarrow \quad r_{p}-r_{f}=\alpha_{p}+\varepsilon_{p}
$$

$r_{m}-r_{f}<0 \quad \rightarrow \quad r_{p}-r_{f}=\alpha_{p}+\left(\beta_{p}-\varphi_{p}\right)\left(r_{m}-r_{f}\right)+\varepsilon_{p}$

It is important to notice that the parameter $\beta_{p}$ in the equation (15) represents the beta coefficient of a portfolio in the up market conditions, while the parameter $\left(\beta_{p}-\varphi_{p}\right)$ in the equation (17) represents the beta coefficient of the portfolio in the down market conditions. The difference between the beta coefficient of a portfolio in the up market conditions $\left(\beta_{p}\right)$ and the beta coefficient of the portfolio in the down market conditions $\left(\beta_{p} \varphi_{p}\right)$ is represented by a parameter $\varphi_{p}$ :

$$
\beta_{p}-\left(\beta_{p}-\varphi_{p}\right)=\varphi_{p}
$$

Considering that the presence of the market timing ability implies that the value of the portfolio's beta coefficient in the up market conditions is larger than the portfolio's beta coefficient in the down market conditions, the parameter $\varphi_{p}$ must have a positive value.

Accordingly, it can be concluded that the Henriksson-Merton model uses the market timing coefficient $\left(\varphi_{p}\right)$ as the measure of the forecaster's (fund manager's) timing ability. The interpretation of the value of the mentioned market timing coefficient fully corresponds to that of the market timing coefficient $\left(\gamma_{p}\right)$ in the Treynor-Mazuy model:
- Positive value of the market timing coefficient $\left(\varphi_{p}>0\right)$ indicates that the portfolio manager of the mutual fund has the timing ability,

- If the value of the market timing coefficient equals zero $\left(\varphi_{p}=0\right)$ this indicates that the portfolio manager of the mutual fund has no timing ability,

- Negative value of the market timing coefficient $\left(\varphi_{p}<0\right)$ indicates that the portfolio manager of the mutual fund wrongly predicts the market movements and makes the wrong decisions concerning the structure of the portfolio and the value of the portfolio's beta coefficient.

The Henriksson-Merton model is graphically represened by two separate straight characteristic lines: a characteristic line for the up market and a characteristic line for the down market. The characteristic line for the up market corresponds to the equation (15), while the characteristic line for the down market corresponds to the equation (17). By analyzing the slopes of the mentioned lines, the following conclusions on the presence or the absence of the market timing ability can be drawn:

- If the characteristic line for the up market has a steep slope, and the characteristic line for the down market has a gentle slope, the portfolio manager of the mutual fund is said to have the timing ability (Figure 6),

- If both characteristic lines have the same slope at an angle of 45 degrees, the portfolio manager of the mutual fund has no timing ability (Figure 7),

- If the characteristic line for the up market has a mild slope, and the characteristic line for the down market has a steep slope, the portfolio manager of the mutual fund failed in terms of the market timing and also made the wrong decisions which did not match the ongoing situation in the market (Figure 8).

Figure 6 illustrates the Henriksson-Merton model in the case when the market timing coefficient has a positive value $\left(\varphi_{p}>0\right)$. 
investicionog fonda ne menja betu portfolija bez obzira na promenu tržišnih okolnosti i nastupajuća tržišna kretanja.

Konačno, grafički prikaz HenrikssonMerton modela za slučaj negativnog koeficijenta tržišnog tajminga $\left(\varphi_{p}<0\right)$ je odraz u ogledalu grafičkog prikaza ovog modela za slučaj pozitivnog koeficijenta tržišnog tajminga $\left(\varphi_{p}>0\right)($ Slika 8):

Slika 8: Grafički prikaz Henriksson-Merton modela za slučaj $\varphi_{p}<0$

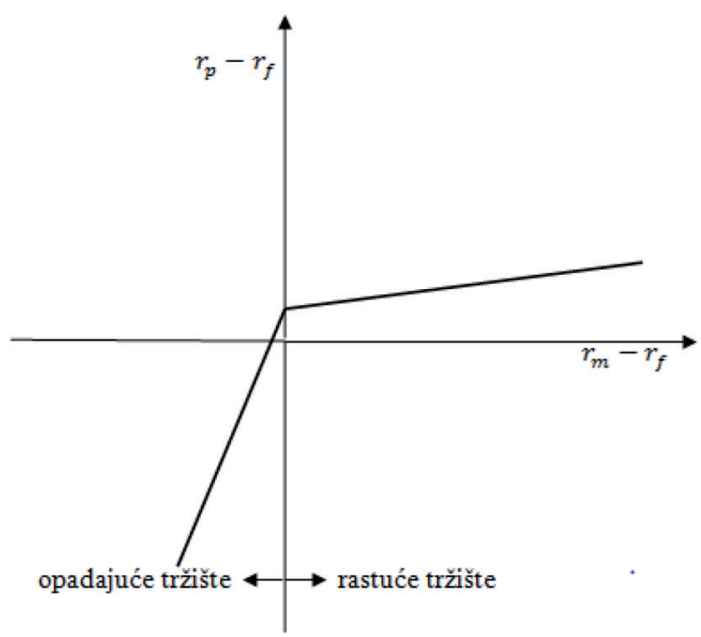

Izvor: Autor

Henriksson-Merton model za slučaj negativnog koeficijenta tržišnog tajminga podrazumeva blag nagib karakteristične linije u fazi rastućeg tržišta i strm nagib karakteristične linije u fazi opadajućeg tržišta. Niska tržišna izloženost portfolija u uslovima rastućeg tržišta rezultira ispodprosečnim prinosima, dok visoka tržišna izloženost portfolija u uslovima opadajućeg tržišta rezultira natprosečnim gubicima. Ispodprosečni prinosi ostvareni u uslovima rastućeg tržišta i natprosečni gubici postignuti u uslovima opadajućeg tržišta ukazuju na loš tajming tržišta i pogrešno strukturiranje portfolija od strane portfolio menadžera investicionog fonda.

Na kraju treba istaći da se ključna razlika između Treynor-Mazuy i Henriksson-Merton modela ogleda u činjenici da u Treynor-Mazuy modelu beta koeficijent portfolija uzima različite vrednosti, dok je u Henriksson-Merton modelu ovaj koeficijent, uvođenjem veštačke varijable $D$, ograničen na dve vrednosti $\beta_{p}$ i $\left(\beta_{p}-\varphi_{p}\right)$ . Različite vrednosti beta koeficijenta portfolija u Treynor-Mazuy modelu uslovljavaju grafičko predstavljanje ovog modela pomoću konveksne karakteristične linije, dok dve potencijalne vrednosti beta koeficijenta portfolija $u$ Henriksson-Merton modelu uslovljavaju grafičko predstavljanje ovog modela pomoću dve odvojene prave karakteristične linije. Dakle, o različitim vrednostima beta koeficijenta portfolija u Treynor-Mazuy modelu svedoči konveksna karakteristična linija, dok o dvema potencijalnim vrednostima beta koeficijenta portfolija u Henriksson-Merton modelu svedoče dve odvojene prave karakteristične linije.

\section{Sortinov racio}

Razvoj PMPT osamdesetih godina 20. veka uslovio je pojavu nove mere performansi portfolija poznate kao Sortinov racio. Sortinov racio su, kao modifikovanu verziju Šarpovog indeksa, uveli Sortino i Price (1994). Za razliku od Šarpovog indeksa koji predstavlja višak prinosa portfolija iznad bezrizične stope prinosa po jedinici ukupnog rizika, Sortinov racio pokazuje višak prinosa portfolija iznad minimalno prihvatljivog prinosa (Minimum Acceptable Return - MAR) po jedinici negativnog rizika. Dakle, Sortinov racio se ne zasniva na ukupnom (pozitivnom i negativnom) riziku, već isključivo na negativnom riziku i negativnoj devijaciji kao njegovoj meri. Dobija tako što se razlika između prosečnog prinosa portfolija i MAR podeli sa negativnom devijacijom (Feibel, 2003):

$$
S_{r}=\frac{\left(\bar{r}_{p}-T\right)}{\sqrt{\frac{\sum\left(r_{p i}-T\right) ; r_{p i}<T}{N}}},
$$

gde su:

$S_{r}$ - Sortinov racio,

$\bar{r}_{p}$ - prosečan prinos portfolija $p$,

$T$ - minimalno prihvatljiva ili ciljana (zahtevana) stopa prinosa (target rate of return), $r_{p i}$ - prinos portfolija $p \mathrm{u} i$-toj opservaciji, $N$ - broj opservacija.

Nije teško zaključiti da se Sortinov racio računa na sličan način kao Šarpov indeks, s tim što se $\mathrm{u}$ brojiocu umesto bezrizične stope prinosa koristi $M A R$, a $\mathrm{u}$ imeniocu umesto standardne devijacije koristi se negativna devijacija. U prethodnoj jednačini izraz $r_{p i}<T$ ukazuje da je imenilac usmeren isključivo na volatilnosti prinosa portfolija ispod ciljane stope prinosa. Odstupanja prinosa portfolija 
Figure 6: Illustration of the HenrikssonMerton model where $\varphi_{p}>0$

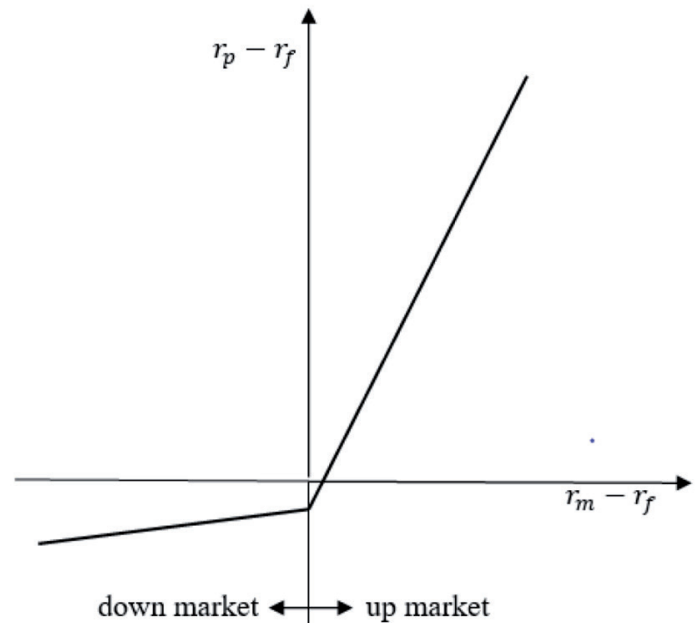

Source: Author, based on Sharpe et al., 1995

The Henriksson-Merton model in the case of a positive market timing coefficient is characterized by a characteristic line with a steep slope in the up market period and a characteristic line with a mild slope in the down market period. The steep slope of the characteristic line in the up market period indicates a high value of the beta coefficient and the high market exposure of the portfolio, while the mild slope of the characteristic line in the down market period points to the low value of the beta coefficient and the low market exposure of the portfolio. The high market exposure of the portfolio in the up market conditions results in the above average returns, while thelow market exposure of the portfolio in the down market conditions results in the below average losses. The above average returns achieved in the up market period and the below average losses achieved in the down market conditions confirm that the mutual funds' portfolio managers indeed have the timing ability.

The figure below illustrates the HenrikssonMerton model in the case when the market timing coefficient $\left(\varphi_{p}=0\right)$ equals zero.
Figure 7: Illustration of the HenrikssonMerton model where $\varphi_{p}=0$

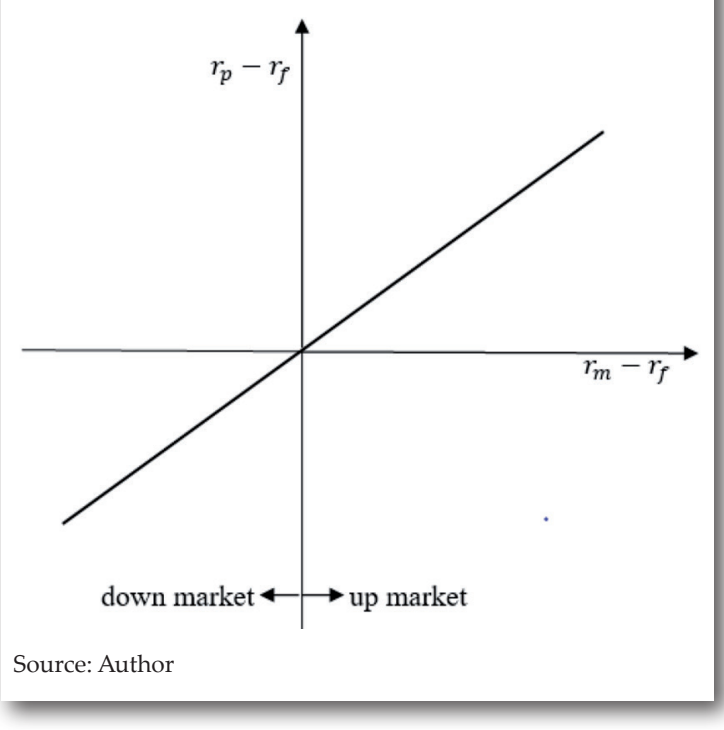

The difference in relation to the graphical representation of the Treynor-Mazuy model in the case when the market timing coefficient equals zero $\left(\gamma_{i}=0\right)$ is reflected in the fact that the graphical representation of the Henriksson-Merton model implies the use of two characteristic lines. The identical slopes of two characteristic lines represented in the relevant figures point to the fact that the portfolio manager has no ability to predict the market fluctuations and accordingly change the structure of the portfolio in due time. Namely, the portfolio manager of the mutual fund does not properly adjust the beta of the portfolio, regardless of the changes in market conditions and the forthcoming market movements.

Finally, the graphical representation of the Henriksson-Merton model in the case when the market timing coefficient has a negative value $\left(\varphi_{p}<0\right)$ can be considered as a reflection in the mirror of this model's graphical representation in the case when the market timing coefficient has a positive value $\left(\varphi_{p}>0\right)$ (Figure 8): 
iznad $M A R$ se ne smatraju rizičnim, i stoga ne uzimaju u obzir prilikom utvrđivanja rizika.

Za razliku od standardne devijacije koja meri i podjednako tretira kako pozitivna, tako i negativna odstupanja prinosa od srednje vrednosti, negativna devijacija meri samo odstupanja prinosa ispod MAR. Negativna devijacija je mera disperzije prinosa ispod od strane investitora zahtevane stope prinosa. Zagovornici PMPT ističu da je čak i Heri Markovic (Harry Markowitz), polazeći od različitih preferencija investitora, priznao da je negativna devijacija preciznija mera rizika od standardne devijacije, jer je samo negativan rizik relevantan za investitore. Međutim, pošto je optimizacija portfolija upotrebom negativne devijacije u to vreme bila računski nepraktična, Markovic je u svojoj teoriji ipak upotrebio standardnu devijaciju.

Da bi se omogućilo poređenje performansi portfolija različitih investicionih fondova, Sortinov racio za svaki pojedinačni fond mora da koristi isti MAR. Varijacija Sortinovog racija koja se koristi kako bi olakšala poređenje performansi različitih fondova podrazumeva upotrebu viška prinosa portfolija iznad bezrizične stope prinosa $\mathrm{u}$ brojiocu i negativne devijacije $\mathrm{u}$ imeniocu. Ukoliko MAR odgovara bezrizičnoj stopi prinosa i ukoliko je distribucija prinosa normalna, vrednost Sortinovog racija biće jednaka vrednosti Šarpovog indeksa, jer će negativna devijacija biti proporcionalna standardnoj devijaciji. Ipak, pojedini autori, poput Sortino i Price (1994), ističu da upotreba bezrizične stope prinosa umesto $M A R$ umanjuje korisnost Sortinovog racija kao mere performansi prilagođene ciljevima investitora. Stoga se, kao srednje rešenje, umesto $M A R$ predlaže upotreba prosečne tržišne stope prinosa koja omogućava široku komparaciju performansi portfolija različitih investicionih fondova (CFA Institute, 2012).

Na kraju treba ukazati na problem praktične primene Sortinovog racija ukoliko u okviru posmatranog perioda ne postoje ili postoji svega par prinosa nižih od MAR. Takođe, kritičari ovog racija ističu da se pored negativnih volatilnosti i pozitivne volatilnosti prinosa moraju uzeti u obzir, jer su postignute preuzimanjem rizika. $S$ druge strane, Sortinovom raciju se daje prednost u slučaju asimetrične, a naročito pozitivno asimetrične distribucije prinosa.

\section{Dekompozicija performansi portfolija}

Nakon primene opisanih mera performansi portfolija važno je izvršiti dekompoziciju ostvarenih performansi portfolija investicionih fondova. Dekompozicija performansi podrazumeva podelu ukupnog prinosa portfolija na sastavne elemente, a vrši se sa ciljem utvrđivanja izvora performansi. Da li je, na primer, izvor natprosečnih performansi selekciona sposobnost portfolio menadžera investicionog fonda ili pak njegova sposobnost tajminga tržišta.

Brojni napori učinjeni $u$ ovom pravcu rezultirali su različitim modelima dekompozicije, a kao najčešće navođeni model izdvaja se dekompozicija ukupnog prinosa koju je izvršio Fama (1972) (Slika 9).

Slika 9: Dekompozicija performansi portfolija investicionih fondova

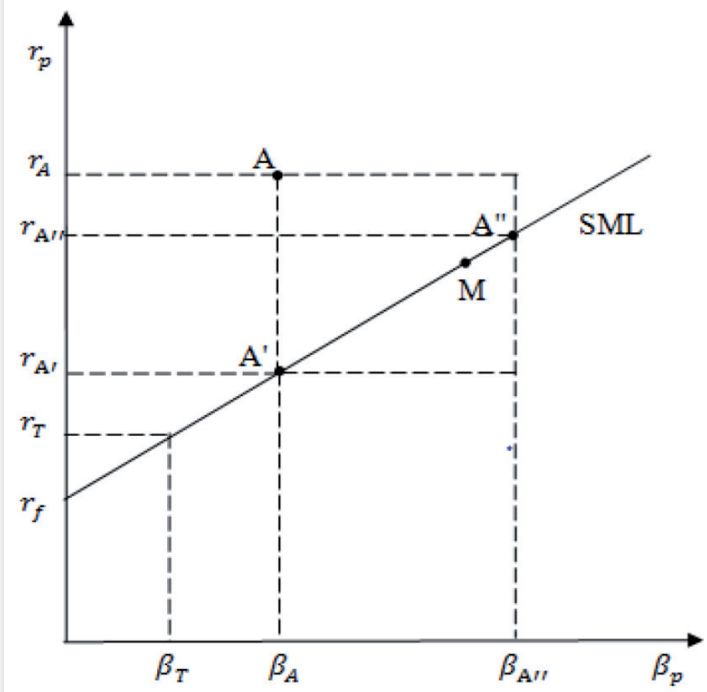

Izvor: Elton i saradnici, 2011

Ukupan prinos i sistemski rizik portfolija A, čije su performanse predmet dekompozicije, označeni su sa $r_{A}$ i $\beta_{A}$. Budući da se portfolio A nalazi iznad tržišne linije hartija od vrednosti (Security Market Line - SML) njegov alfa indeks je pozitivan $\left(\alpha_{i}>0\right)$, a ostvarene performanse superiorne $\mathrm{u}$ odnosu na tržište. Vertikalno rastojanje između pozicije portfolija A i $S M L$ linije $\left(\mathrm{A}-\mathrm{A}^{\prime}\right)$ označava prinos ostvaren zahvaljujući selekcionoj sposobnosti portfolio menadžera $\left(r_{A}-r_{\mathrm{A}^{\prime}}\right)$. Portfoliji A i A imaju jednake sistemske rizike merene beta koeficijentima, ali se njihovi ukupni rizici 
Figure 8: Illustration of the HenrikssonMerton model where $\varphi_{p}<0$

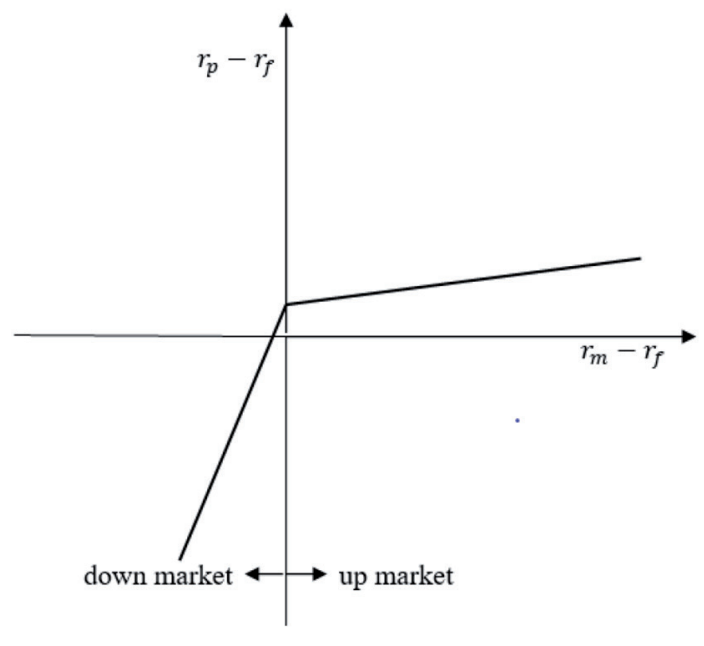

Source: Author

The Henriksson-Merton model in the case when the market timing coefficient has a negative value implies a mild slope of the characteristic line in the up market conditions and a steep slope of the characteristic line in the down market conditions. The low market exposure of the portfolio in the up market conditions results in the below average returns, while the high market exposure of the portfolio in the down market conditions results in the above average losses. The below average returns achieved in the up market conditions and the above average losses achieved in the down market conditions point to the bad market timing and improper structuring of the portfolio by the portfolio manager of the relevant mutual fund.

Finally, it should be noted that the key difference between the Treynor-Mazuy model and the Henriksson-Merton model is reflected in the fact that in the Treynor-Mazuy model, the portfolio's beta coefficient can take different values, while in the Henriksson-Merton model, the beta coefficient, due to the introduction of the dummy variable $D$, is limited to only two values $\beta_{p}$ and $\left(\beta_{p}-\varphi_{p}\right)$. The different values of the portfolio's beta coefficient in the Treynor-Mazuy model require this model to be graphically represented by a convex characteristic line, while the two potential values of the beta coefficient in the Henriksson-Merton model require this model to be graphically represented by means of two separate straight characteristic lines. Therefore, the different values of the portfolio's beta coefficient in the Treynor-Mazuy model are indicated by a convex characteristic line, whereas the two potential values of the portfolio's beta coefficient in the Henriksson-Merton model are indicated by two separate straight characteristic lines.

\section{Sortino Ratio}

The development of the PMPT in the 1980s brought about the emergence of a new portfolio performance measure known as the Sortino ratio. The Sortino ratio, as a modified version of the Sharpe ratio, was introduced by Sortino and Price (1994). Unlike the Sharpe ratio, which represents the excess return of the portfolio above the risk-free rate of return per unit of total risk, the Sortino ratio shows the excess portfolio return above the minimum acceptable return $(M A R)$ per unit of negative risk. Therefore, the Sortino ratio is not based on the total (upside and downside) risk, but only on the downside risk and the downside deviation as the measure of that risk. The Sortino ratio is calculated by subtracting the $M A R$ from the average return of the portfolio and then dividing this difference by the downside deviation (Feibel, 2003):

$$
S_{r}=\frac{\left(\bar{r}_{p}-T\right)}{\sqrt{\frac{\sum\left(r_{p i}-T\right) ; r_{p i}<T}{N}}}
$$

where:

$S_{r}$ - denotes the Sortino ratio,

$\bar{r}_{p}$ - denotes the average return of the portfolio $p$,

$T$ - denotes the minimum acceptable or target rate of return,

$r_{p i}$ - denotes the return of the portfolio $p$ in the $i$-th observation,

- denotes the number of observations.

Therefore, it is easy to conclude that the Sortino ratio is calculated in a similar way as the Sharpe ratio, except for the fact that instead of the risk free rate of return used as the numerator in the Sharpe ratio, the Sortino ratio uses the $M A R$, while in terms of the denominator, the Sharpe ratio uses standard deviation, whereas the Sortino ratio uses the downside deviation. In the equation given above, the expression $r_{p i}<T$ indicates that the denominator solely implies the volatility of the portfolio return below the target rate of return. The deviations 
razlikuju. Ukupan rizik portfolija $\mathrm{A}^{\prime}$ je jednak njegovom sistemskom riziku, dok je ukupan rizik portfolija A veći, jer pored sistemskog sadrži i nesistemski rizik. Na prisustvo nesistemskog rizika ukazuje pozicija portfolija A iznad $S M L$ linije, jer linearnu kombinaciju tržišnog portfolija i bezrizične aktive predstavljaju samo oni portfoliji koji leže na SML liniji (Blake, 2000). Dakle, u cilju ostvarenja većeg prinosa držanje portfolija A podrazumeva podnošenje ne samo sistemskog, već i nesistemskog rizika. Navedena konstatacija gubi na značaju ukoliko je pored portfolija A i brojna druga aktiva $u$ vlasništvu investitora, jer će se nesistemski rizik eliminisati diversifikacijom. Međutim, ukoliko investitor ne poseduje drugu značajnu aktivu osim portfolija A, kao ključno nameće se pitanje: da li je ekstra prinos vredan ekstra rizika (Elton i saradnici, 2011)?

Odgovor na postavljeno pitanje zahteva upoređivanje portfolija A sa portfolijom koji leži na $S M L$ liniji i ima jednak nivo ukupnog rizika (portfolio $\mathrm{A}^{\prime \prime}$ ). Pošto je prinos portfolija A veći od prinosa portfolija $A^{\prime \prime}$ zaključuje se da je dodatni prinos vredan podnošenja dodatnog rizika (Blake, 2000). Razlika između prinosa portfolija A i prinosa portfolija $\mathrm{A}^{\prime \prime}$ $\left(r_{A}-r_{\mathrm{A}^{n}}\right)$ je prinos ostvaren zahvaljujući čistoj selekcionoj sposobnosti portfolio menadžera, dok je razlika između prinosa portfolija $\mathrm{A}^{\prime \prime} \mathrm{i}$ prinosa portfolija $\mathrm{A}^{\prime}\left(r_{\mathrm{A}^{\prime \prime}}-r_{\mathrm{A}^{\prime}}\right)$ dodatni prinos ostvaren preuzimanjem nesistemskog rizika. Prema tome, Fama (1972) u okviru prvog dela dekompozicije performansi, vrši podelu prinosa ostvarenog zahvaljujući selekcionoj sposobnosti portfolio menadžera $\left(r_{A}-r_{\mathrm{A}^{\prime}}\right)$ na prinos ostvaren zahvaljujući čistoj selekcionoj sposobnosti portfolio menadžera $\left(r_{A}-r_{\mathrm{A}^{n}}\right) \mathrm{i}$ prinos ostvaren preuzimanjem nesistemskog rizika $\left(r_{\mathrm{A}^{\prime \prime}}-r_{\mathrm{A}^{\prime}}\right)$ (Slika 9).

Predmet drugog dela dekompozicije je prinos ostvaren podnošenjem sistemskog rizika, predstavljen razlikom između prinosa portfolija $\mathrm{A}^{\prime} \mathrm{i}$ bezrizične stope prinosa $\left(r_{\mathrm{A}^{\prime}}-r_{f}\right)$. Uz pretpostavku poznavanja ciljanog (targetiranog) nivoa rizika koji su investitori spremni da prihvate, prinos ostvaren podnošenjem sistemskog rizika $\left(r_{\mathrm{A}^{\prime}}-r_{f}\right)$ se deli na prinos koji investitori očekuju da će ostvariti po osnovu preuzimanja ciljanog nivoa rizika $\left(r_{T}-r_{f}\right)$ i prinos koji se ostvaruje po osnovu preuzimanja rizika većeg od ciljanog $\left(r_{\mathrm{A}^{\prime}}-r_{T}\right)$. Na preuzimanje rizika većeg od ciljanog portfolio menadžeri se odlučuju ukoliko očekuju rast tržišta, zbog čega smanjivanjem učešća bezrizične aktive povećavaju betu portfolija. Prinos ostvaren na ovaj način je ništa drugo do prinos ostvaren zahvaljujući sposobnosti tajminga tržišta portfolio menadžera investicionih fondova.

Na osnovu prethodno navedenog zaključuje se da se ukupan prinos analiziranog portfolija A može razložiti na sledeće komponente: 1) bezrizični prinos $\left.\left(r_{f}\right), 2\right)$ prinos ostvaren preuzimanjem ciljanog rizika $\left.\left(r_{T}-r_{f}\right), 3\right)$ prinos ostvaren uspešnim tajmingom tržišta $\left(r_{\mathrm{A}^{\prime}}-r_{T}\right)$, 4) prinos ostvaren preuzimanjem nesistemskog rizika $\left(r_{\mathrm{A}^{\prime \prime}}-r_{\mathrm{A}^{\prime}}\right)$ i 5) prinos ostvaren zahvaljujući čistoj selekcionoj sposobnosti portfolio menadžera $\left(r_{A}-r_{\mathrm{A}^{n}}\right)$.

\section{Zaključak}

Važnost ocene performansi portfolija investicionih fondova ogleda se $\mathrm{u}$ činjenici da, $s$ jedne strane, investitorima pruža informacije o uspešnosti portfolio menadžmenta, a $\mathrm{s}$ druge strane, portfolio menadžerima pruža informacije o prednostima i slabostima kreiranog portfolija.

Pored afirmisanih Šarpovog, Trejnorovog i Jensenovog ili alfa indeksa, u finansijskoj literaturi su se izdvojile i dve modifikovane verzije Šarpovog indeksa: informacioni racio i $M^{2}$ mera performansi portfolija, kao i jedna modifikovana verzija Trejnorovog indeksa: $T^{2}$ mera performansi portfolija. Posebno mesto među modelima ocene performansi portfolija investicionih fondova zauzimaju TreynorMazuy model i Henriksson-Merton model koji mere menadžersku sposobnost tajminga tržišta, a pažnju zavređuje i Sortinov racio zasnovan na negativnoj devijaciji kao meri negativnog rizika. Svrha primene prethodno navedenih mera performansi portfolija je da se utvrdi da li je portfolio investicionog fonda ostvario prosečne, natprosečne ili ispodprosečne rezultate, kao i da se razume uzrok dobrih ili loših performansi investicionih fondova. $\mathrm{S}$ tim $\mathrm{u}$ vezi, važno je izvršiti dekompoziciju ostvarenih performansi portfolija, odnosno, utvrditi da li su ostvareni rezultati postignuti zahvaljujući 
of the portfolio return above the MAR are not considered risky, and therefore are not taken into consideration when determining the risk.

Unlike the standard deviation, which measures and equally considers both the upside and downside deviations of the return from the mean value, the downside deviation measures only the deviations of return below the MAR. The downside deviation is a measure of the dispersion of return below the rate of return which is required by investors. The PMPT proponentspointout thateven Harry Markowitz, starting from the different preferences of the investors, acknowledged that the downside deviation is a more accurate measure of risk than the standard deviation, because it is only the downside risk that is relevant to investors. However, since the portfolio optimization by means of the downside deviation at the time was too complex to calculate, Markowitz opted for the standard deviation.

In order to be able to compare the performance of the portfolios belonging to different mutual funds, for each of these funds the Sortino ratio must use the same MAR. The variation of the Sortino ratio used to facilitate the comparison of performance of different funds involves the use of excess portfolio returns above the risk-free rate of return in the numerator and downside deviation in the denominator. If the $M A R$ corresponds to the risk-free rate of return, and if there is a normal distribution of returns, the value of the Sortino ratio will be equal to the value of the Sharpe ratio, because the downside deviation will be proportional to the standard deviation. However, some authors, including Sortino and Price (1994), point out that using the risk-free rate of return instead of the MAR reduces the usefulness of the Sortino ratio as a performance measure which takes into account the objectives of the investors. Therefore, as a compromising solution, it was suggested to use the average market rate of return instead of the $M A R$, because it allows the extensive comparison of portfolio performance of different investment funds (CFA Institute, 2012).

Finally, it should be noted that there is a problem in terms of the practical application of the Sortino ratio in the case when there are no returns below the $M A R$ or when there are just few such returns during the observed period. Also, the critics underline that this ratio, in addition to the downside volatility, should also consider the upside volatility because the upside volatility is also achieved by taking some risks. On the other hand, the Sortino ratio is given priority in the case of the asymmetric distribution of returns, and in particular in the case of the positive asymmetric distribution of returns.

\section{Decomposition of Portfolio Performance}

After applying the described portfolio performance measures, it is important to perform the decomposition of the actual portfolio performance of mutual funds. The decomposition of performance implies breaking down the overall return of the portfolio into its segments, and is conducted in order to determine the source of such portfolio performance. For example, whether the above average performance of some portfolio is achieved due to the portfolio manager's selection ability or due to his/her timing ability.

Numerous efforts have been made to address this issue and, as a result, different decomposition models have been derived. However, the most commonly used model is the model developed by Fama (1972), which focuses on the decomposition of the overall returns (Figure 9).

Figure 9: Decomposition of the mutual funds' portfolio performance

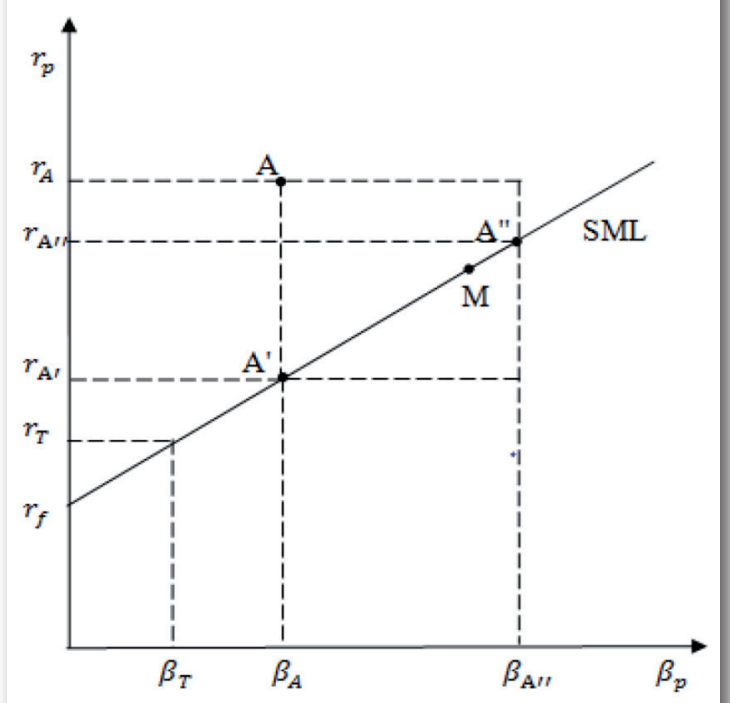

Source: Elton et al., 2011 
prisustvu (odsustvu) selekcione sposobnosti i/ ili prisustvu (odsustvu) sposobnosti tajminga tržišta portfolio menadžera fonda.

Rezultati dekompozicije performansi portfolija predstavljaju svojevrsnu smernicu daljim potezima portfolio menadžera investicionih fondova. Ukoliko portfolio menadžeri imaju sposobnost tajminga tržišta, ali nemaju sposobnost izbora "pravih“ hartija od vrednosti, predlaže im se investiranje u indeksni portfolio, uz sopstveni izbor kombinacije indeksnog portfolija i bezrizične aktive. $S$ druge strane, ukoliko portfolio menadžeri ne uspevaju da tajmingom tržišta ostvare pozitivan prinos, ali poseduju selekcionu sposobnost, predlaže im se da vrše izbor hartija od vrednosti, ali da drugima prepuste odluku o kombinaciji kreiranog rizičnog portfolija i bezrizične aktive, tj. odluku o preuzimanju ili ne preuzimanju rizika većeg od ciljanog. U prethodno navedenom ogleda se važnost dekompozicije ostvarenih performansi portfolija, odnosno, važnost poznavanja uzroka dobrih ili loših performansi portfolija investicionih fondova. 
The overall return and systemic risk of the portfolio $\mathrm{A}$, whose performance is the subject of decomposition, are denoted by $r_{A}$ and $\beta_{A}$. Since the portfolio $\mathrm{A}$ is located above the security market line $(S M L)$, it has a positive alpha index $\left(\alpha_{i}>0\right)$, and it outperforms the market, i.e. the achieved performance is superior to that of the market. The vertical distance between the position of the portfolio A and the SML $\left(\mathrm{A}-\mathrm{A}^{\prime}\right)$ indicates that the excessive return was achieved due to the selection ability of the portfolio manager $\left(r_{A}-r_{\mathrm{A}^{\prime}}\right)$. The portfolios $\mathrm{A}$ and $\mathrm{A}^{\prime}$ have the same systemic risk measured by their respective beta coefficients, but they do not have the same total risk. The total risk of the portfolio $\mathrm{A}^{\prime}$ is equal to its systemic risk, whereas the total risk of the portfolio $\mathrm{A}$ is higher, because in addition to the systemic risk it also includes the non-systemic risk. The presence of the non-systemic risk is indicated by the position of the portfolio A which is above the $S M L$, since only those portfolios characterized by the linear combination of the market portfolio and the riskfree assets are positioned, i.e. lie on the $S M L$ line (Blake, 2000). Hence, in order to achieve higher returns, the composition of the portfolio A must include both systemic and non-systemic risks. This statement loses its significance if, in addition to the portfolio $\mathrm{A}$, the investor holds numerous other assets, because in this case the non-systemic risk will be eliminated due to diversification. However, if the investor does not hold any other significant assets other than the portfolio A, an important question arises: is the extra return worth the extra risk (Elton et al., 2011)?

In order to answer this question, we need to compare the portfolio A with the portfolio which lies on the SML has the same level of total risk as the portfolio A (portfolio A"). Since the return of the portfolio $\mathrm{A}$ is greater than the return of the portfolio $\mathrm{A}^{\prime \prime}$, we can conclude that the extra return is worth taking the extra risk (Blake, 2000). The difference between the return of the portfolio $\mathrm{A}$ and the return of the portfolio $\mathrm{A}^{\prime \prime}\left(r_{A}-r_{\mathrm{A}^{\prime \prime}}\right)$ is the return achieved thanks to the selection ability of the portfolio manager, while the difference between the return of the portfolio $\mathrm{A}^{\prime \prime}$ and the return of the portfolio $\mathrm{A}^{\prime}$ $\left(r_{\mathrm{A}^{\prime \prime}}-r_{\mathrm{A}^{\prime}}\right)$ is the extra return achieved by taking the non-systemic risk. Therefore, Fama (1972) in the first stage of the portfolio performance decomposition performs the decomposition of the return achieved due to the selection ability of the portfolio manager $\left(r_{A}-r_{\mathrm{A}^{\prime}}\right)$ breaking it down to the return achieved due to exclusive selection ability of the portfolio manager $\left(r_{A}-r_{\mathrm{A}^{\mathrm{N}}}\right)$ and the return achieved by taking nonsystemic risk $\left(r_{\mathrm{A}^{\prime \prime}}-r_{\mathrm{A}^{\prime}}\right)$ (Figure 9).

The second stage implies the decomposition of the return achieved by taking systemic risk, which is represented by the difference between the return of the portfolio $\mathrm{A}^{\prime}$ and the risk-free rate of return $\left(r_{\mathrm{A}^{\prime}}-r_{f}\right)$. Assuming that we know the target risk level the investors are willing to accept, the return achieved by taking systemic risk $\left(r_{\mathrm{A}^{\prime}}-r_{f}\right)$ is divided into the return that the investors expect to achieve by taking the target risk level $\left(r_{T}-r_{f}\right)$ and the return which is achieved by taking the risk greater than the target risk level $\left(r_{\mathrm{A}^{\prime}}-r_{T}\right)$. The portfolio managers opt for taking the risks which are greater than the target risk level if they expect market growth, therefore by lowering the share of the risk-free assets, they increase the portfolio's beta. The return achieved this way is actually the return achieved due to the timing ability of the portfolio managers of the mutual funds.

Based on the above discussion, it can be concluded that the total return of the analyzed portfolio A can be disaggregated into the following components: 1$)$ the risk-free return $\left.\left(r_{f}\right), 2\right)$ the return achieved by taking the target risk level $\left.\left(r_{T}-r_{f}\right), 3\right)$ the return achieved due to the successful market timing $\left.\left(r_{\mathrm{A}^{\prime}}-r_{T}\right), 4\right)$ the return achieved by taking non-systemic risk $\left(r_{\mathrm{A}^{\prime \prime}}-r_{\mathrm{A}^{\prime}}\right)$ and 5) the return achieved thanks to the exclusive selection ability of the portfolio manager $\left(r_{A}-r_{\mathrm{A}^{n}}\right)$.

\section{Conclusion}

The significance of the portfolio performance evaluation of mutual funds is reflected in the fact that, on the one hand, it provides the information to the investors on the effectiveness of portfolio management, and on the other hand, it informs the portfolio managers about the strengths and weaknesses of the constructed portfolio.

In addition to the well-established performance measures, the Sharpe ratio, the Treynor ratio and the Jensen's or alpha 


\section{Literatura / References}

1. Blake, D. (2000). Financial Market Analysis. Chichester, England: John Wiley \& Sons Ltd.

2. Bodie, Z., Kane, A., \& Marcus, A. J. (2009). Osnovi investicija. Beograd, Republika Srbija, Data status.

3. CFA Institute (2011). The Sharpe Ratio and the Information Ratio. Retrieved September 22, 2016, from http://www.cfapubs.org/doi/ pdf/10.2469/ipmn.v2011.n1.7.

4. CFA Institute (2012). The Sortino Ratio: Is Downside Risk the Only Risk that Matters?. Retrieved October 05, 2016, from http:// www.cfapubs.org/doi/pdf/10.2469/ipmn. v2012.n1.1.

5. Elton, E. J., Gruber, M. J., Brown, S. J., \& Goetzmann, W. N. (2011). Modern Portfolio Theory and Investment Analysis. Hoboken, New Jersey: John-Wiley \& Sons Inc.

6. Fabozzi, F. J., Grant, J. L., \& Vardharaj, R. (2011a). Common Stock Portfolio Management Strategies. In F. J. Fabozzi, \& H. M. Markowitz (Eds.). The Theory and Practice of Investment Management: Asset Allocation, Valuation, Portfolio Construction, and Strategies (pp. 229-270). Hoboken, New Jersey: John Wiley \& Sons Inc.

7. Fama, E. F. (1972). Components of Investment Performance. The Journal of Finance, 27(3), 551-567.

8. Feibel, B. J. (2003). Investment Performance Measurement. Hoboken, New Jersey: John Wiley \& Sons, Inc.

9. Francis, J. C., \& Kim, D. (2013). Modern Portfolio Theory: Foundations, Analysis and New Developments. Hoboken, New Jersey: John Wiley \& Sons, Inc.
10. Goodwin, H. T. (1998). The Information Ratio. Financial Analysts Journal, 54(4), 34-43.

11. Henriksson, R. D., \& Merton, R. C. (1981). On Market Timing and Investment Performance II: Statistical Procedures for Evaluating Forecasting Skills. The Journal of Business, 54(4), 513-533.

12. Jensen, M. C. (1968). The Performance of Mutual Funds in the Period 1945-1964. Journal of Finance, 23(2), 389-416.

13. Modigliani, F., \& Modigliani, L. (1997). RiskAdjusted Performance. Journal of Portfolio Management, 23, 45-54.

14. Sharpe, W. F. (1966). Mutual Fund Performance. Journal of Business, 39, 119-138.

15. Sharpe, W. F., Alexander, G. J., \& Bailey, J. V. (1995). Investments. Englewood Cliffs, New Jersey: Prentice Hall Inc.

16. Sortino, F. A., \& Price, L. N. (1994). Performance Measurement in a Downside Risk Framework. The Journal of Investing, 3(3), 59-64.

17. Treynor, J. L. (1965). How to Rate Management of Investment Funds. Harvard Business Review, 43, 63-73.

18. Treynor, J. L., \& Mazuy, K. K. (1966). Can Mutual Funds Outguess the Market?. Harvard Business Review, 43, 131-136.

19. Treynor, J. L., \& Black, F. (1973). How to Use Security Analysis to Improve Portfolio Selection. The Journal of Business, 46(1), 66-86. 
index, the financial literature also includes other alternative portfolio measures, such as: two modified versions of Sharpe ratio - i.e. the information ratio and the $M^{2}$ portfolio performance measure and one modified version of the Treynor ratio - i.e. the $T^{2}$ portfolio performance measure. The TreynorMazuy and the Henriksson-Merton model which measure the market timing abilities of fund managers have a special place among the portfolio performance evaluation models. The Sortino ratio based on the downside risk and the downside deviation as the measure of such risk should also be given attention due to its relevance. The purpose of applying the abovementioned portfolio performance measures is to determine whether the portfolio of some investment fund has achieved average, above average or below average results, as well as to understand the cause of successful or poor performance of mutual funds. In this regard, it is important to carry out the decomposition of the actual portfolio performance, i.e. to determine whether the achieved results have been achieved thanks to the presence (absence) of the selection ability and/or the presence (absence) of the timing ability of the mutual fund manager.
The results of the portfolio performance decomposition serve as guidance for the further actions of mutual fund portfolio managers. If portfolio managers possess the timing ability, but do not have the ability to choose the "right" securities, it is suggested that they invest in an index portfolio, personally choosing the combination of the index portfolio and the risk-free assets. On the other hand, if portfolio managers fail to achieve excess returns based on their market timing ability, but they do possess the selection ability, they are suggested to perform the selection of securities, however, they should let others decide on the mix of the constructed risky portfolio and the riskfree assets, i.e. they should let other managers decide whether to take or not the risks greater than the target risk level. The importance of the actual portfolio performance decomposition, i.e. the importance of being familiar with the causes of successful or poor portfolio performance of mutual funds, is confirmed by the aforementioned facts. 